\title{
Synthesis, Characterization, Electrochemistry and Computational Studies of Ferrocenyl-substituted Siloles
}

\author{
Steve W. Lehrich, ${ }^{\dagger}$ Alexander Hildebrandt, ${ }^{\dagger}$ Tobias Rüffer, ${ }^{\dagger}$ Marcus Korb, ${ }^{\dagger}$ Paul J. Low ${ }^{\ddagger}$ and Heinrich \\ Lang ${ }^{\dagger, *}$ \\ †Technische Universität Chemnitz, Faculty of Natural Sciences, Institute of Chemistry, Inorganic Chemistry, Straße der \\ Nationen 62, D-09111 Chemnitz, Germany \\ ${ }^{\ddagger}$ School of Chemistry and Biochemistry, University of Western Australia, Crawley, Perth, Western Australia, Australia \\ Supporting Information Placeholder
}

\begin{abstract}
Ferrocenylsiloles of the type 2,5- $\mathrm{Fc}_{2}-3,4-\mathrm{Ph}_{2}{ }^{-} \mathrm{C}_{4} \mathrm{SiR}_{2}(3 \mathrm{a}, \mathrm{R}=\mathrm{Me} ; 3 \mathrm{~b}, \mathrm{R}=\mathrm{Ph}$ ) have been prepared by reductive cyclization from diethynyl silanes, followed by ferrocenylation using the Negishi C,C cross coupling protocol with the silole ring serving as either the vinyl halogenide species or as zinc organic component and the complementary functionality introduced on the ferrocenyl moiety. The electrochemical behavior of these silacyclic-bridged bis(ferrocenyl) complexes was investigated by cyclic and square wave voltammetry, and the nature of the redox products studied by in situ UV-vis/NIR spectroelectrochemical measurements. Each of $3 \mathrm{a}$ and $3 \mathrm{~b}$ undergoes two sequential ferrocenyl-based redox processes, the separation of each $\left(E^{\circ 1}=E_{2}{ }^{\circ 1}-E_{1}{ }^{\circ 1}=300 \mathrm{mV}(3 \mathrm{a}) ; 280 \mathrm{mV}(3 \mathrm{~b})\right)$ is in the range of structural similar systems such as 2,5-diferrocenyl-1-phenyl-1H-phosphole $(280 \mathrm{mV})$ and 2,5-diferrocenylfuran $(290 \mathrm{mV})$. Interestingly, the more electron-rich silole $3 \mathrm{~b}$, compared to $3 \mathrm{a}$, shows a modestly lower redox separation between the individual ferrocenyl oxidation processes, which may be due to the capacity of this group to shield the effect of an adjacent positive charge. An inter-valence charge transfer (IVCT) absorption was found in the in situ NIR measurements for $[3 a]^{+}$and $[3 b]^{+}$, the analysis of which is consistent with a moderate electronic interaction between the iron atoms through the cis-diene-like fragment of the silole bridge, and allowing description as Robin and Day class II mixedvalence systems. These conclusions are supported by results from quantum chemical calculations, which also reveal the likely presence of a range of molecular conformations in solution.
\end{abstract}

\section{INTRODUCTION}

Silicon-containing metalloles (metallacyclopentadienes) are useful structural and electronic building blocks that can be used as monomers for the preparation of conjugated polymers ${ }^{1,2}$ or copolymers. ${ }^{3,4}$ For example, Tamao has presented an $\pi$ conjugated thiophene silole co-polymer, ${ }^{5}$ whilst polysilole (PS) or silolecontaining co-polymers, which are linked through the 2,5-position exhibit unique conductivity and semiconducting properties attributed to the small band gap $\left(E_{\mathrm{g}}\right),{ }^{6-8}$ with computational studies indicating that PS has an even smaller band gap than other fivemembered polyheterocycles such as polythiophene (PT, $E_{g}=2.10$ $\mathrm{eV})$ and polypyrrole $\left(\mathrm{PP}, \mathrm{E}_{\mathrm{g}}=2.85 \mathrm{eV}^{9}\right) .^{7,10}$ These properties make silicon-containing metalloles interesting motifs for use in the design of organic semiconductors. In addition, due to the high electron mobility and high photoluminescence quantum yields, 1 silacyclopentadienes have attracted much interest for a diverse range of other materials applications such as new display devices or in organic light-emitting diodes (OLEDs), according to the interaction of the * orbital of the Si-C bond with the $\pi^{*}$ orbital of the butadiene fragment. ${ }^{11-14}$

In order to gain a deeper insight into the electron transfer process that can be propagated through a single repeating unit of such polymers, and in the light of our recent research on heterocyclopentadienes ${ }^{15-17}$ and aromatic five-membered heterocycles ${ }^{18-23}$ we became interested in siloles as $\pi$ conjugated bridging units between two redox-active ferrocenyl termini. Herein, we present the synthesis and structural characterization of siloles of type 2,5- $\mathrm{Fc}_{2}-3,4-\mathrm{Ph}_{2}{ }^{\mathrm{c}} \mathrm{C}_{4} \mathrm{SiR}_{2}(\mathrm{R}=\mathrm{Me}, \mathrm{Ph})$, together with an electrochemical study of their redox chemistry and spectroelectrochemical investigation of the redox products. Computational calculations were carried out to enhance our understanding of the electronic structure of the compound in different oxidation states.

\section{RESULTS AND DISCUSSION}

Synthesis and Characterisation. Silacyclopentadienes $2 \mathrm{a}$ and $2 \mathrm{~b}$ were synthesized by intramolecular reductive cyclization from dimethyl-bis(phenylethynyl)silane (1a) and diphenylbis(phenylethynyl)silane (1b) with lithium naphthalenide followed by bromination with elemental bromine, forming dibromide $2 \mathrm{a}$, or the reaction with $\left[\mathrm{ZnCl}_{2} \cdot 2\right.$ thf] giving the zinc organic species $2 \mathrm{~b}$ (Scheme 1). Applying Negishi-ferrocenylation conditions, the reaction of $2 \mathrm{a}$ with $\mathrm{FcZnCl}\left(\mathrm{Fc}_{\mathrm{C}}=\mathrm{Fe}\left({ }^{5}-\mathrm{C}_{5} \mathrm{H}_{4}\right)\left({ }^{5}-\mathrm{C}_{5} \mathrm{H}_{5}\right)\right)$ as ferrocenyl source and $\left[\mathrm{Pd}\left(\mathrm{CH}_{2} \mathrm{CMe}_{2} \mathrm{P}^{t} \mathrm{Bu}_{2}\right)(\mu-\mathrm{Cl})\right]_{2}$ as precatalyst gave silole $3 \mathrm{a}$. The analog coupling of 2,5- $\mathrm{Br}_{2}-3,4-\mathrm{Ph}_{2}{ }^{-} \mathrm{C}_{4} \mathrm{SiPh}_{2}$ with ferrocenyl zinc chloride did not result in the formation of desired $3 \mathrm{~b}$. The synthesis of $3 \mathrm{~b}$ was realized by a Negishi C,C cross-coupling reaction using iodoferrocene as ferrocenyl source, while the application of bromoferrocene was unsuccessful. After appropriate work up (Experimental Section), molecules $3 \mathbf{a}$ and $3 \mathbf{b}$ were obtained in moderate ( $3 a$ ) to low ( $3 b$ ) yield as dark red solids. 


\section{Scheme 1 Synthesis of 3a and $3 \mathrm{~b}$ using Negishi Conditions ${ }^{\mathrm{a}}$}

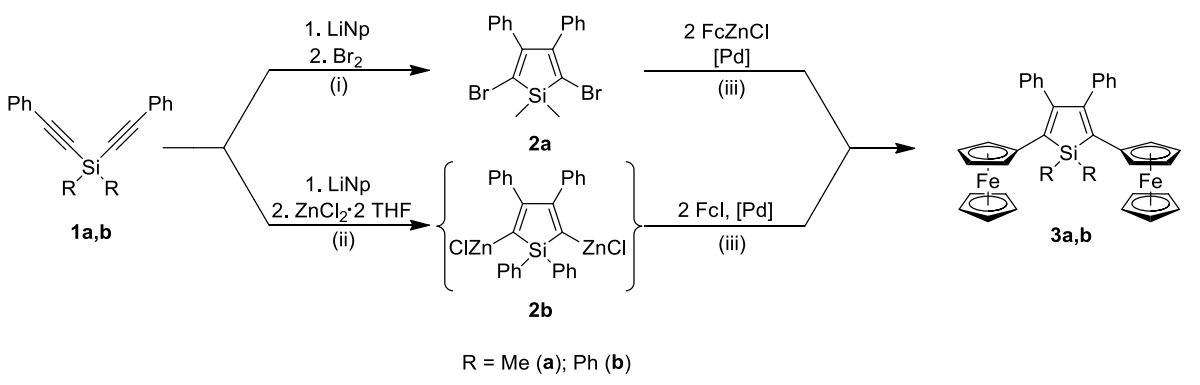

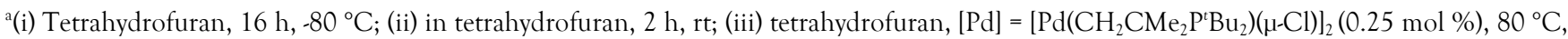
$2 \mathrm{~d} ; \mathrm{LiNp}=$ lithium naphthalenide; $\mathrm{Fc}=\mathrm{Fe}\left({ }^{5}-\mathrm{C}_{5} \mathrm{H}_{4}\right)\left({ }^{5}-\mathrm{C}_{5} \mathrm{H}_{5}\right)$.

Siloles $3 \mathbf{a}, \mathbf{b}$ are stable towards air, light and moisture in the solid state and in solution and were each characterized by elemental analysis, UV-vis, IR and NMR $\left({ }^{1} \mathrm{H},{ }^{13} \mathrm{C}\left\{{ }^{1} \mathrm{H}\right\},{ }^{29} \mathrm{Si}\left\{{ }^{1} \mathrm{H}\right\}\right)$ spectroscopy and mass spectrometry. The molecular structure of $3 \mathbf{a}$ and $3 \mathrm{~b}$ in the solid state was determined by single crystal X-ray structure analysis. The electrochemical behavior of $3 \mathbf{a}, \mathbf{b}$ was examined by cyclic voltammetry $(\mathrm{CV})$, square wave voltammetry (SWV) and in situ UV-vis/NIR spectroelectrochemistry. Furthermore, DFT calculations were carried out to support the conclusions drawn from the spectroscopic measurements and enhance the understanding of the underlying electronic structures of $[3 a, b]^{n+}(n$ $=0,1,2)$.

The ${ }^{1} \mathrm{H}$ NMR spectra of $3 \mathbf{a}, \mathbf{b}$ show the characteristic pattern for the two equivalent ferrocenyl groups with one singlet $\left(\mathrm{C}_{5} \mathrm{H}_{5}\right)$ and two pseudotriplets $\left(\mathrm{C}_{5} \mathrm{H}_{4}\right)$ with $J=1.90 \mathrm{~Hz}$, the latter characteristic for AA'XX' spin systems. ${ }^{24}$ The signal of the $\mathrm{C}_{5} \mathrm{H}_{5}$ group is found at $4.06 \mathrm{ppm}$ for $3 \mathrm{a}$ and $3.52 \mathrm{ppm}$ for $3 \mathrm{~b}$. The ${ }^{13} \mathrm{C}\left\{{ }^{1} \mathrm{H}\right\}$ and ${ }^{29} \mathrm{Si}\left\{{ }^{1} \mathrm{H}\right\}$ NMR spectra show typical resonances corresponding to the heterocyclic core and the methyl- and the phenyl-groups (Experimental Section). ${ }^{25}$ High resolution mass spectrometry (HRMS) displays an anticipated $\mathrm{m} / \mathrm{z}$ peak of 630.1298 for $3 \mathrm{a}$ and 754.1425 for $3 b$
Single crystals of $3 \mathrm{a}$ and $3 \mathrm{~b}$ in form of $3 \mathrm{~b} 2 \mathrm{CH}_{2} \mathrm{Cl}_{2}$ suitable for $\mathrm{X}$ ray diffraction analysis could be obtained by diffusion of $n$-hexane into a dichloromethane solution containing either $3 \mathrm{a}$ or $3 \mathrm{~b}$ at ambient temperature. The molecular structures of $3 a$ and $3 \mathbf{b}$ in the solid state together with selected bond distances $(\AA)$ and bond angles $\left({ }^{\circ}\right)$ are shown in Figure 1.

Molecule 3a crystallizes in the orthorhombic space group Pbca with $\mathrm{C}_{1}$ symmetry and $3 \mathrm{~b}$ in the monoclinic space group $P 2 / \mathrm{n}$ with two dichloromethane molecules. In contrast to $3 \mathrm{a}$, silole $3 \mathrm{~b}$ possesses a $\mathrm{C}_{2}$ symmetry axis going through the $\mathrm{Si} 1$ atom and the middle of the C2-C2' bond (Figure 1). For 3a, the ferrocenyl groups are oriented in syn-fashion, and are located on the same side of the silacycle, while in $3 \mathrm{~b}$ an anti-conformation is observed, similar to the structure determined for other bis(ferrocenyl)metallocycles. ${ }^{15}$ In the case of $3 \mathrm{~b}$, the anti-configuration is apparently stabilized by intramolecular $\pi$ interactions ${ }^{26,27}$ between the ferrocenyl moieties and the phenyl groups pendant to the silicon atom (Figure 2). These $\pi$ interactions also seem to cause the high-field shift of the C5H5 protons of $3 \mathrm{~b}$ when compared with $3 \mathrm{a}$ (3a: $4.06 \mathrm{ppm} ; 3 \mathrm{~b}$ : $3.52 \mathrm{ppm})$ 


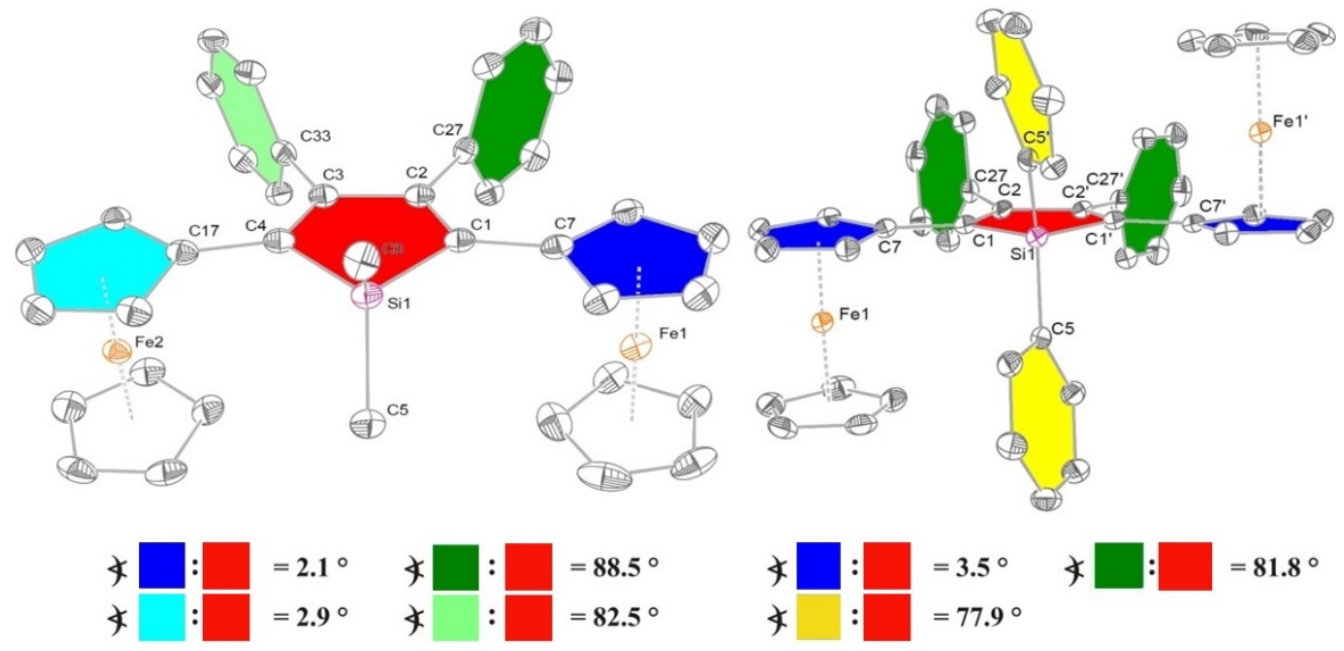

Figure 1. ORTEP diagram (50\% probability level) of the molecular structure of $3 \mathrm{a}$ (left) und $3 \mathrm{~b}$ (right) with the atom-numbering scheme. The sign $\Varangle$ indicates interplanar angles between calculated mean planes of atoms adjoining differently coloured areas. All hydrogen atoms have been omitted for clarity. Selected bond distances $(\AA)$, angles $\left(^{\circ}\right)$, and torsion angles $\left({ }^{\circ}\right)$ : $3 \mathrm{a}$ : $\mathrm{Si} 1-\mathrm{C} 1=1.8787(16) . \mathrm{C} 1-\mathrm{C} 2=1.359(2), \mathrm{C} 1-\mathrm{C} 7=$ 1.463(2), Si1-C4 = 1.8817(16), Si1-C5 = 1,8710(17), Si1-C6 = 1.8692(17), C2-C3 = 1.498(2), C2-C27 = 1.494(2), C3-C33 = 1.494(2), C3-C4 = $1.360(2), \mathrm{C} 4-\mathrm{C} 17=1.462(2)$, average D-Fe $=1.649 ; \mathrm{C} 2-\mathrm{C} 1-\mathrm{Si} 1=107.31(11) \mathrm{C} 1-\mathrm{Si} 1-\mathrm{C} 4=92.26(7)$, average D-Fe-D = 177.43. 3b: Si-C1 = 1.871(4). C1-C2 = 1.353(5), C1-C7 = 1.463(5), Si1-C5 = 1.870(3), C2-C2A = 1.507(6), C2-C27 = 1.491(5), average D-Fe = 1.648; C2-C1-Si1 = 107.0 (2) C1-Si1-C1A $=93.0(2)$, average D-Fe-D $=177.4$. D denotes the centroid of $\mathrm{C}_{5} \mathrm{H}_{4}$ or $\mathrm{C}_{5} \mathrm{H}_{5}$. Symmetry operation for generating equivalent atoms: ' $=-\mathrm{x}+1 / 2, \mathrm{y},-\mathrm{z}+5 / 2$.

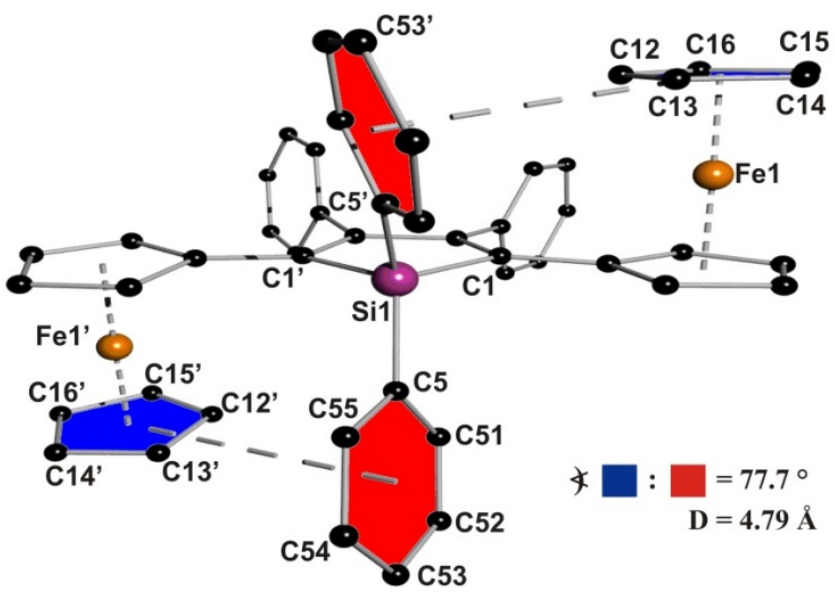

Figure 2. Ball-and-stick model of the molecular structure of $3 b$ displaying intramolecular $\pi$ interactions between the aromatic $\mathrm{C}_{5} \mathrm{H}_{5}$ and $\mathrm{Ph}_{\mathrm{Si}}$ functionalities. All hydrogen atoms are omitted for clarity. The sign $\Varangle$ refers to the calculated interplanar angle and D to the distance of the geometrical centroids of $\pi$ interacting aromatic units. Symmetry operation for generating equivalent atoms: ' $=-x+1 / 2, y,-z+5 / 2$.
In $3 \mathbf{a}, \mathbf{b}$ the bond distances within the central $\mathrm{SiC}_{4}$ heterocyclic silole cores each display the same short-long alternation, consistent with the valence bond description of the silacyclopentadiene (Scheme 1, Figure 1), whilst the distances between the silacycle and the ferrocenyl ipso carbon atoms are indistinguishable (3a 1.436(2), $1.432(2)$; 3b 1.436(5) А). Furthermore, the bond distances of the silole core of $3 \mathbf{a}, \mathbf{b}$ are identical to those reported for $1,1,2,3,4,5$ hexaphenylsilole and $^{289}$ and 1,1-dimethyl-2,3,4,5-tetraphenylsilole, ${ }^{30}$ respectively. These observations might indicate that the substitution of the 2,3,4,5-bonded phenyl groups by ferrocenyl moieties or the Si-bonded phenyl groups by methyl groups have a negligible influence on structural parameters.

The ferrocenyl ligands are almost coplanar with the heterocyclic core (torsion angles of the $\mathrm{C}_{5} \mathrm{H}_{4}$ plane to the silacyclopentadiene unit: 3a, 2.07(3) ${ }^{\circ}$ for $\mathrm{Fe} 1,2.88(3)^{\circ}$ for Fe2; 3b, 3.5 ${ }^{\circ}$ for $\mathrm{Fe} 1$ and $\left.\mathrm{Fe} 1^{\prime}\right)$. In $3 \mathbf{a}, \mathbf{b}$ the phenyls in 3,4-position are almost orthogonal to the heterocyclic core (torsion angles of the phenyl plane to the silacyclopentadiene unit: $3 \mathrm{a}, 88.49(6)^{\circ}, 82.47(6)^{\circ}$; $\left.3 \mathrm{~b}, 81.8^{\circ}\right)$. The conformation of the cyclopentadienyls in all ferrocenyl ligands are almost eclipsed $\left(3 \mathrm{a},-7.64(11)^{\circ}\right.$ for $\mathrm{Fe} 1$ and $0.80(10)^{\circ}$ for $\mathrm{Fe} 2 ; 3 \mathrm{~b}$, $-2.30^{\circ}$ for $\mathrm{Fe} 1$ ). In both compounds, $3 \mathrm{a}$ and $3 \mathrm{~b}$, the central $\mathrm{SiC}_{4}$ cores are planar with the silicon atom possessing, as expected, a tetrahedral environment. ${ }^{31}$ 

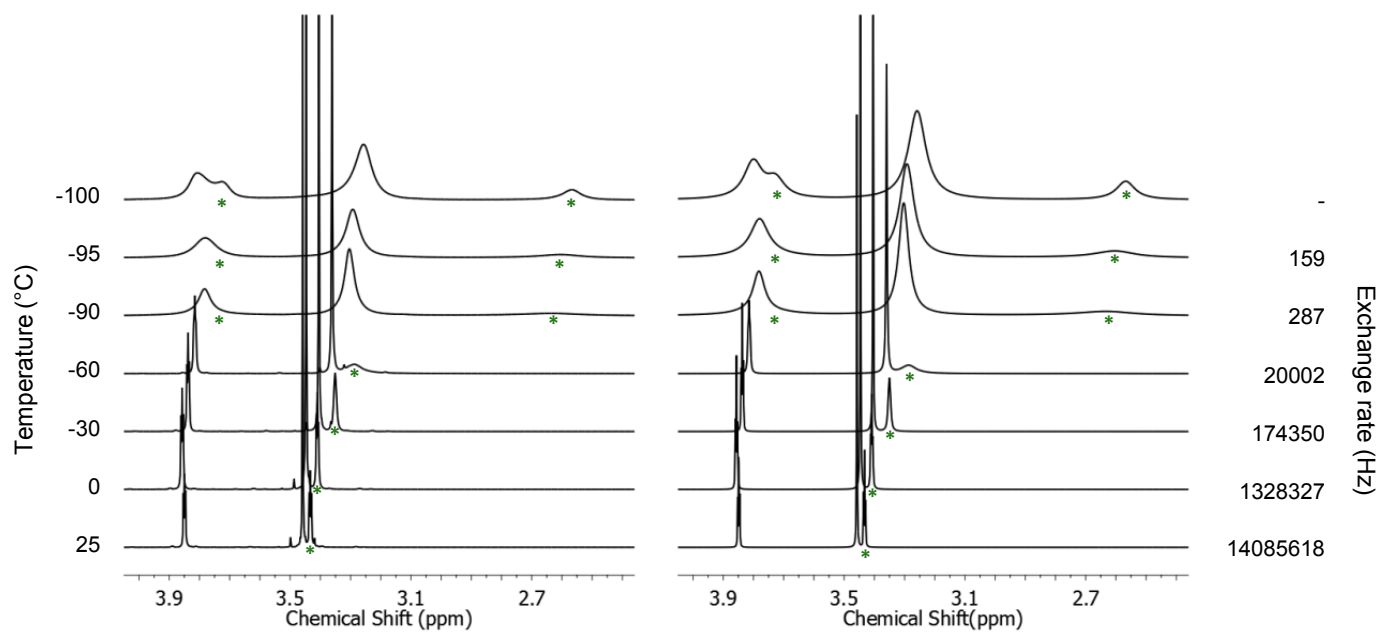

Figure 3. Left: experimental ${ }^{1} \mathrm{H}$ NMR spectra of $3 \mathrm{~b}$ between 2.36 and 4.05 ppm.; dichloromethane- $\mathrm{d}_{2}$; at various temperatures; Right: simulated ${ }^{1} \mathrm{H}$ NMR spectra of $3 \mathrm{~b}$ with different exchange rates. Protons in $\alpha, \alpha^{\prime}$-position of the $\mathrm{C} 5 \mathrm{H} 4$ ring are marked with an asterisk.

Given the stabilization of the ferrocenyls' orientation by $\pi$ interactions with the phenyl substituents at the silicon atom the free rotation around the silole-ferrocenyl carbon-carbon bond could be reduced by cooling NMR samples of $3 \mathrm{~b}$ to $-100{ }^{\circ} \mathrm{C}$. The exchange rates of those protons can be determined by line-shapefitting of the NMR spectra at the appropriate temperatures (Figure 3). The activation parameters of the rotations could be quantified from the exchange rates in graphical analysis according to Eyring ${ }^{32,33}$ to $\Delta H^{*}=38.6( \pm 1.5) \mathrm{kJ} \mathrm{mol}^{-1}$ and $\Delta S^{*}=18.2( \pm 7) \mathrm{J} \mathrm{mol}^{-}$ ${ }^{1} \mathrm{~K}^{1}$ (Supporting Information Figure SI16). Comparison with similar rotation energy barriers in 2,3,4,5-tetraferrocenyl-N-phenyl1- $H$-pyrrole $\left(\Delta H^{*}=26.8( \pm 1.2) \mathrm{kJ} \mathrm{mol}^{-1} / \Delta S^{*}=-94.1( \pm 4.5) \mathrm{J} \mathrm{mol}^{-}\right.$ $\left.{ }^{1} \mathrm{~K}^{-1}\right)^{19}$ showed that the activation enthalpy of $3 \mathrm{~b}$ is ca. $12 \mathrm{~kJ} \mathrm{~mol}^{-1}$ higher, which in part may be attributed to the T-shaped $\pi-\pi$ interaction (Figure 2). Sherrill and coworkers showed in 2002 that such aromatic T-shaped interactions can reach stabilization energies of $9-12 \mathrm{~kJ} \mathrm{~mol}^{-1}$ for the benzene dimer. ${ }^{26}$ Furthermore, in contrast to 2,3,4,5-tetraferrocenyl-N-phenyl-1-H-pyrrole ${ }^{19}$ the activation entropy of the ferrocenyl rotation in $3 \mathrm{~b}$ is positive. This is generally the case, when the transition state exhibits more degrees of freedom than the ground state. The $\pi-\pi$ interaction not only hinders the rotation of the ferrocenyls, but also limits the freedom of rotation for the $\mathrm{C} 5 \mathrm{H} 5$ rings and the phenyl groups. Therefore, the ground states of the rotation around the siloleferrocenyl carbon-carbon bond could be considered entropically unfavourable hence resulting in a positive activation entropy. The observations of dynamic NMR studies not only support the crystallographic determined $\pi-\pi$ interaction but also showed that even in solution especially at low temperatures a rotation barrier of the ferrocenyls is present and should be taken into consideration. Please, note that, due to the absence of $\pi-\pi$ interaction in $3 \mathrm{a}$ no rotation barrier could be observed at temperatures down to $-100^{\circ} \mathrm{C}$ (Supporting information Figure SI17).

Electrochemistry. The electrochemical properties of $3 \mathrm{a}, \mathrm{b}$ were investigated by cyclic voltammetry $(\mathrm{CV})$, square wave voltammetry (SWV) (Figure 4) and the nature of the redox products was explored in more detail by in situ UV-vis/NIR spectroelectrochemistry (Figure 5). The voltammetric measurements were carried out in dry dichloromethane solutions of $\left[\mathrm{N}^{n} \mathrm{Bu}_{4}\right]\left[\mathrm{B}\left(\mathrm{C}_{6} \mathrm{~F}_{5}\right)_{4}\right]\left(0.1 \mathrm{~mol} \mathrm{~L} \mathrm{~L}^{-1}\right)$, the latter being chosen to minimize ion pairing effects ${ }^{34-36}$ (examples for application of $\left[\mathrm{N}^{n} \mathrm{Bu}_{4}\right]\left[\mathrm{B}\left(\mathrm{C}_{6} \mathrm{~F}_{5}\right)_{4}\right]$ as supporting electrolyte within electrochemical measurements see references $\left.{ }^{15,19,22,37-41}\right)$. Cyclic voltammetry studies were performed at $25^{\circ} \mathrm{C}$ with a scan rate of $100 \mathrm{mV} \mathrm{s}^{-1}$. All potentials are referenced to the $\mathrm{FcH} / \mathrm{FcH}^{+}\left(\mathrm{FcH}=\mathrm{Fe}\left({ }^{5}-\mathrm{C}_{5} \mathrm{H}_{5}\right)_{2}\right)$ redox couple $\left(E^{\circ 1}=0.0 \mathrm{mV}\right){ }^{42}$

\section{Chart 1. Selected Diferrocenyl Molecules for Comparison}

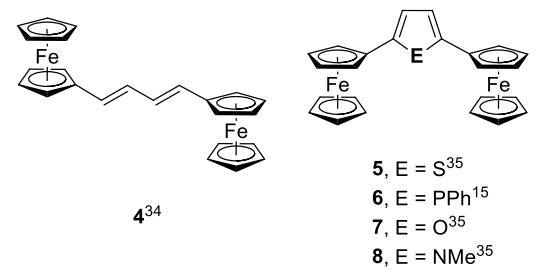

Table 1. Cyclic Voltammetry Data of 3a,b and 4-8 for Comparison

\begin{tabular}{cccc}
\hline Compd. & $\begin{array}{c}E_{1}{ }^{\text {ol }}[\mathrm{mV}]^{a} \\
\left(E_{\mathrm{p}}[\mathrm{mV})^{\mathrm{c}}\right.\end{array}$ & $\begin{array}{c}E_{2}{ }^{\circ 1}[\mathrm{mV}]^{b} \\
\left(E_{\mathrm{p}}[\mathrm{mV}]\right)^{c}\end{array}$ & $E^{\text {ol }}[\mathrm{mV}]^{d}$ \\
\hline $3 \mathrm{a}^{\mathrm{e}}$ & $-145(72)$ & $155(74)$ & 300 \\
$3 \mathrm{~b}^{\mathrm{e}}$ & $-170(64)$ & $110(68)$ & 280 \\
\hline $4^{\mathrm{f}, 43}$ & -35 & 90 & 225 \\
$5^{\mathrm{e}, 44}$ & $-94(65)$ & $166(65)$ & 260 \\
$6^{\mathrm{e}, 15}$ & $-110(72)$ & $170(80)$ & 280 \\
$7^{\mathrm{e}, 44}$ & $-152(60)$ & $138(63)$ & 290 \\
$8^{\mathrm{e}, 44}$ & $-206(65)$ & $204(65)$ & 410
\end{tabular}

${ }^{a} E^{\circ 1}=$ formal potential of first redox process. ${ }^{b} E_{1}{ }^{\text {ol }}=$ formal potential of second redox process. ${ }^{c} E_{\mathrm{p}}=$ difference between oxidation and reduction potentials. ${ }^{d} E^{\circ \prime}=$ potential difference between the two ferrocenyl-related redox processes. ${ }^{e}$ Potentials vs $\mathrm{FcH} / \mathrm{FcH}^{+}$, scan rate $100 \mathrm{mV} \mathrm{s}^{-1}$ at a glassy-carbon electrode of 1.0 mmol L-1 solutions in dry dichloromethane containing $0.1 \mathrm{~mol} \mathrm{~L}^{-1}$ of $\left[\mathrm{N}^{n} \mathrm{Bu}_{4}\right]\left[\mathrm{B}\left(\mathrm{C}_{6} \mathrm{~F}_{5}\right)_{4}\right]$ as supporting electrolyte at $25^{\circ} \mathrm{C}$. ${ }^{f}$ measured in $\left[\mathrm{Bu}_{4} \mathrm{~N}\right]\left[\mathrm{B}\left(3,5-\mathrm{C}_{6} \mathrm{H}_{3}\left(\mathrm{CF}_{3}\right)_{2}\right](0.1 \mathrm{M})\right.$ in dichloromethane working electrode, $\mathrm{Pt}$; reference electrode, $\mathrm{Ag} / \mathrm{AgI}$, referenced to $\mathrm{FcH} / \mathrm{FcH}^{+}$; scan rate, $50 \mathrm{mV} / \mathrm{s}$. 
The ferrocenyl substituents in $3 \mathbf{a}, \mathbf{b}$ are oxidized separately showing two reversible redox events with a redox separation $\left(E^{\text {ol }}=E_{2}{ }^{\text {ol }}\right.$. $\left.E_{1}{ }^{\circ}\right)$ of $300 \mathrm{mV}$ (3a) and $280 \mathrm{mV}$ (3b), respectively, which indicates some through-bond or through-space electronic interactions between the ferrocenyl/ferrocenium termini (Table 1, Figure 4). While for 1,1-dimethyl-2,3,4,5-tetraphenylsilacyclopentadiene irrever-sible oxidation $\left(E_{\mathrm{pa}}=1482 \mathrm{mV}\right)$ and reduction $\left(E_{\mathrm{pc}}=-2174 \mathrm{mV}\right)$ processes have been observed by Tracy $^{31}$, compounds $3 \mathbf{a}, \mathbf{b}$ showed no such redox events within the measured potential range $(-2500-1800 \mathrm{mV})$. Within the series of bis(ferrocenyl) complexes featuring five-membered aromatic heterocyclic bridges, such as $5^{36}, 7^{35}$ and $8^{19}$ (Chart 1) it could be shown that the separation of the two ferrocenyl redox waves depends on the electronic characteristics of the bridging moiety. The more electron-rich the bridging group, the lower (less positive) the first ferrocenyl oxidation $\left(E_{1}{ }^{\circ}\right)$ potential process becomes and hence electron-rich heterocycles show higher $E^{\text {ol }}$ values (Table 1 ). The ${ }^{c} \mathrm{C}_{4} \mathrm{Si}$ bridging unit within silole $3 \mathrm{~b}$ donates more electron density towards the ferrocenyl moieties when compared with 3a and thus those ferrocenyls are more easily oxidized (3a: $E_{1}{ }^{0}=-145$ $\mathrm{mV}, 3 \mathrm{~b}: E_{1}{ }^{\text {ol }}=-170 \mathrm{mV}$ ); however, $3 \mathrm{~b}$ possesses the lower redox separation $(3 \mathrm{a}, 300 \mathrm{mV} ; 3 \mathrm{~b}, 280 \mathrm{mV})$, which is in contrast to the trends revealed by other members of this five-membered heterocyclic family (Table 1). The discrepancy between the observed and expected electrochemical behavior of $3 \mathrm{a}$ and $3 \mathrm{~b}$ might be explained by the influence of the cross-hyperconjugation of the $\mathrm{SiMe}_{2}$ moiety to the butadiene system. ${ }^{12,46-49}$ Due to the involvement of the silicon atom in the $\pi$ conjugation, the electronic interactions between the respective iron centers might be increased, leading to some additional stabilization of the monooxidized redox product $[3 \mathrm{a}]^{+}$relative to $[3 \mathrm{~b}]^{+}$. In order to explore this hypothesis, the IVCT transitions within the mixed-valent cations $[3 \mathrm{a}]^{+}$and $[3 \mathrm{~b}]^{+}$have been studied using spectroelectrochemical methods.

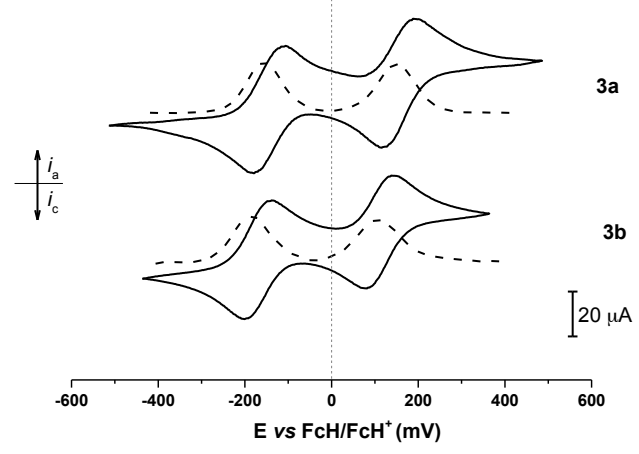

Figure 4. Cyclic voltammograms (solid line) and square wave voltammograms (dotted line) of $3 \mathrm{a}$ and $3 \mathrm{~b}$ in dichloromethane solutions $\left(1.0 \mathrm{mmol} \mathrm{L}^{-1}\right)$ at $25^{\circ} \mathrm{C}\left(\right.$ scan rate $100 \mathrm{mV} \mathrm{s}^{-1}$; supporting electrolyte $0.1 \mathrm{~mol} \mathrm{~L}^{-1}$ of $\left.\left[\mathrm{N}^{n} \mathrm{Bu}_{4}\right]\left[\mathrm{B}\left(\mathrm{C}_{6} \mathrm{~F}_{5}\right)_{4}\right]\right)$.

Spectroelectrochemistry. Spectroelectrochemical studies were performed in an optically transparent thin-layer electrochemistry (OTTLE) cell containing $2.0 \mathrm{mmol} \mathrm{L}^{-1}$ of $3 \mathrm{a}$ or $3 \mathrm{~b}$ and $0.1 \mathrm{~mol} \mathrm{~L}^{-1}$ of $\left[\mathrm{N}^{n} \mathrm{Bu}_{4}\right]\left[\mathrm{B}\left(\mathrm{C}_{6} \mathrm{~F}_{5}\right)_{4}\right]$ as the supporting electrolyte, with stepwise increase of the applied potential from -200 to $700 \mathrm{mV}$ vs $\mathrm{Ag} / \mathrm{AgCl}$. The potential was increased using varying step heights of 25,50 and $100 \mathrm{mV}$. This procedure allowed the sequential in situ generation of $[3 a, b]^{+}$and $[3 a, b]^{2+}$ (Figure 5). In their charge neutral,
Fe(II/II) state, siloles 3a,b are, as expected, transparent in the NIR region, while broad intensive transitions (IVCT and LMCT) could be observed as $3 \mathbf{a}, \mathbf{b}$ were oxidized to $[3 \mathbf{a}]^{+}$and $[3 \mathbf{b}]^{+}$by increasing the applied potential. Deconvolution of this absorption envelope, required four Gaussian-shaped spectral components, consistent with an IVCT transition at $4700 \mathrm{~cm}^{-1}\left([3 \mathrm{a}]^{+}\right)$or $4650 \mathrm{~cm}^{-1}\left([3 \mathrm{~b}]^{+}\right)$ $\left([3 \mathrm{a}]^{+}:{ }_{\max }=3150 \mathrm{~L} \mathrm{~mol}^{-1} \mathrm{~cm}^{-1}, \quad 1 / 2=2950 \mathrm{~cm}^{-1} ;[3 \mathrm{~b}]^{+}:\right.$max $_{\text {ax }}=2270 \mathrm{~L}$ $\left.\mathrm{mol}^{-1} \mathrm{~cm}^{-1}, \quad 1 / 2=3310 \mathrm{~cm}^{-1}\right)$ and two LMCT bands at $3470 \mathrm{~cm}^{-1}$ and $4000 \mathrm{~cm}^{-1}\left([3 \mathrm{a}]^{+}\right)$and $3460 \mathrm{~cm}^{-1}$ and $3930 \mathrm{~cm}^{-1}\left([3 \mathrm{~b}]^{+}\right.$) (Table 2, Figure 6). The fourth component was used to simulate the low energy edge of higher energy absorptions that protrude into the NIR region. Due to the $\mathrm{sp}^{3}$ character of the silicon atom, the silole fragment ${ }^{c} \mathrm{C}_{4} \mathrm{Si}$ is rather comparable to a cis-diene system. ${ }^{43}$ However, the intensity of the IVCT absorption found in [3a $]^{+}$ exceeds those found in mixed valence $[6]^{+15}$ and $[4]^{+},{ }^{43}$ while the IVCT characteristics $\left({ }_{\max }, 1 / 2\right)$ of $[3 b]^{+}$are very similar to those of the diene analog $[4]^{+}$. The higher extinction coefficient of the IVCT absorption in $[3 \mathrm{a}]^{+}$might be a consequence of crosshyperconjugation of the $\mathrm{SiMe}_{2}$ building block with the butadiene unit causing involvement of the $\mathrm{sp}^{3}$ hybridized silicon atom in the $\pi$ conjugated system, a phenomenon that has been described in, for example, methyl- and H-substituted siloles. ${ }^{12,46-49}$ The fact that the IVCT transition associated with $[3 \mathrm{~b}]^{+}$is less intense and broader than that of $[3 \mathrm{a}]^{+}$demonstrates a weaker electronic coupling between the redox centers. In support of this, we note that although $E^{\text {ol }}$ depends on many factors, including ion-pairing energies, solvation factors, magnetic effects and metal-ligand bonding variations in different oxidation states, in addition to statistic and electrostatic terms, ${ }^{50,51}$ these are not expected to be substantively different in $3 a /[3 a]^{+}$vs $3 b /[3 b]^{+}$. Hence, the smaller $E^{\text {ol }}$ value observed for $3 \mathrm{~b}$ (see above electrochemistry) is also consistent with a smaller contribution of the resonance term. Comparison of the characteristics of the IVCT transition of [3a $]^{+}$ and $[3 \mathrm{~b}]^{+}$with those from other aromatic five-membered heterocycles revealed that the ${ }_{1 / 2}$ values for $[5]^{+}, 21,45,52[6]^{+}, 15[7]^{+}, 44$ $[8]^{+44,53,54}$ are smaller $\left(2300-2400 \mathrm{~cm}^{-1}\right)$ than those of $[3 \mathrm{a}]^{+}$and $[3 \mathrm{~b}]^{+}$, while the intensities are within the same range. Phosphole $[6]^{+},{ }^{+15}$ which is similar to siloles $3 \mathrm{a}, \mathrm{b}$ also contains a non-aromatic five membered heterocycle showing IVCT absorptions with $1 / 2$ values comparable to $[3 \mathbf{a}]^{+}$and $[3 \mathrm{~b}]^{+}$, respectively.

Table 2. NIR Data of the Absorptions of Siloles [3a $]^{+}$and $[3 b]^{+}$.

\begin{tabular}{|c|c|c|c|c|c|c|}
\hline \multicolumn{2}{|r|}{ Compd. } & \multirow{2}{*}{$\frac{\left(\left(\mathrm{L} \mathrm{mol}^{\max } \mathrm{cm}^{-1}\right)\right)}{4700(3150)}$} & \multirow{2}{*}{$\frac{\begin{array}{c}1 / 2 \\
\left(\mathrm{~cm}^{-1}\right)\end{array}}{2950}$} & \multirow{2}{*}{ 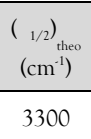 } & \multirow{2}{*}{$\begin{array}{c}\begin{array}{c}\mathrm{H}_{\mathrm{ab}} \\
\left(\mathrm{cm}^{-1}\right)^{b}\end{array} \\
\text { syn conformation }\end{array}$} & \multirow{2}{*}{$\begin{array}{c}\begin{array}{c}\mathrm{H}_{\mathrm{ab}} \\
\left(\mathrm{cm}^{-1}\right)^{b}\end{array} \\
\text { anti conformation } \\
500\end{array}$} \\
\hline \multirow{3}{*}{$3 \mathrm{a}^{+}$} & IVCT & & & & & \\
\hline & I LMCT & $3470(2650)$ & 950 & & & \\
\hline & II LMCT & $4000(1250)$ & 450 & & & \\
\hline \multirow{3}{*}{$3 b^{+}$} & IVCT & $4650(2250)$ & 3300 & 3300 & 482 & 445 \\
\hline & I LMCT & $3460(1450)$ & 800 & & & \\
\hline & II LMCT & $3930(800)$ & 450 & & & \\
\hline
\end{tabular}

$\left[\mathrm{N}^{n} \mathrm{Bu}_{4}\right]\left[\mathrm{B}\left(\mathrm{C}_{6} \mathrm{~F}_{5}\right)_{4}\right]$ as supporting electrolyte at $25^{\circ} \mathrm{C}$. ${ }^{\mathrm{b}} \mathrm{H}_{\mathrm{ab}}$ was calculated according to equation 1 with $r_{\mathrm{ab}, \text { syn }}=7.9438 \AA$ and $r_{\mathrm{ab}, \text { anti }}$ $=8.6074 \AA$.

$$
H_{a b}=2.06 \cdot 10^{-2} \cdot \frac{\sqrt{v_{\max } \varepsilon_{\max } \cdot \Delta v_{1 / 2}}}{r_{a b}}
$$


The electronic coupling parameter $H_{\mathrm{ab}}$ can be calculated according to Hush's two state model for a class II system as shown in Eq 1, where $r_{\mathrm{ab}}$ is the effective electron transfer distance between the two redox active sites, which is notoriously hard to determine experimentally ${ }^{51,55-58}$ Therefore, the crystallographic $\mathrm{Fe}-\mathrm{Fe}$ distances were used to estimate $H_{\mathrm{ab}}$. Since the ferrocenyl substituents within $3 \mathrm{a}, \mathrm{b}$ can adopt both, a syn- and an anticonformation, $H_{\mathrm{ab}}$ was calculated using crystallographic data derived from 3a representing the syn-orientation $\left(\mathrm{r}_{\mathrm{ab}, \mathrm{syn}}=7.9438\right.$ (18) $\AA$ ) and anti-oriented 3b ( $r_{\mathrm{ab}, \text { anti }}=8.6074$ (9) $\AA$ ). Please, note that the effective electron transfer distance is expected to be shorter than the geometric $\mathrm{Fe}-\mathrm{Fe}$ distances and hence $H_{\mathrm{ab}}$ might be underestimated. ${ }^{54}$ As expected, due to the lower $r_{\mathrm{ab}}$ value $H_{\mathrm{ab}}$ is higher for the syn-conformation for both molecules [3a $]^{+}$and $[3 b]^{+}$, when compared with the respective anti-conformer (Table 2). Silole $[3 a]^{+}$exhibits higher $H a b$ values when compared with $[3 b]^{+}$, nevertheless, the determined values are quite similar showing that there are only minor differences in the electronic coupling caused by the different substitution on the silicon atom.

The unexpected strong IVCT interactions allowed to classify siloles $[3 \mathbf{a}]^{+}$and $[3 \mathbf{b}]^{+}$as moderately or moderately to weakly coupled class II system, respectively, according to the classification system introduced by Robin and Day. ${ }^{58}$
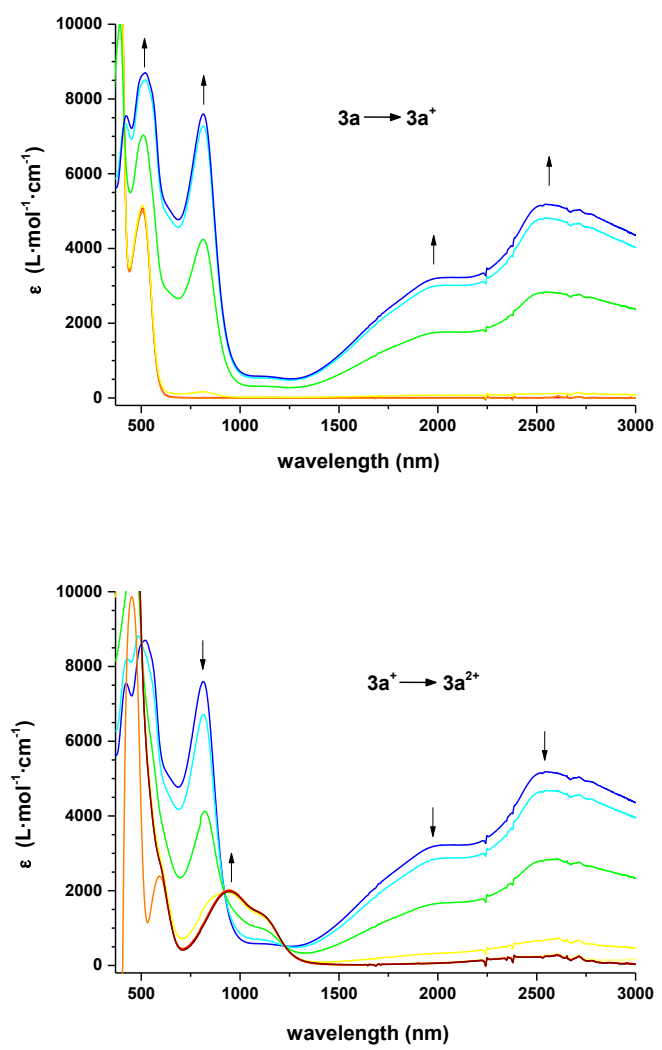

Figure 5. UV-vis/NIR spectra of $[3 a]^{n+}(n=0,1,2)$ in dichloromethane solution $\left(2.0 \mathrm{mmol} \mathrm{L}^{-1}\right)$ at rising potentials (top: $200 \mathrm{mV}$ to $300 \mathrm{mV}$, bottom: $300 \mathrm{mV}$ to $700 \mathrm{mV}$ vs $\mathrm{Ag} / \mathrm{AgCl}$ ) at 25 ${ }^{\circ} \mathrm{C}$; supporting electrolyte $0.1 \mathrm{~mol} \mathrm{~L}^{-1}$ of $\left[\mathrm{N}^{n} \mathrm{Bu}_{4}\right]\left[\mathrm{B}\left(\mathrm{C}_{6} \mathrm{~F}_{5}\right)_{4}\right]$. Arrows indicates an increase or decrease of absorptions.

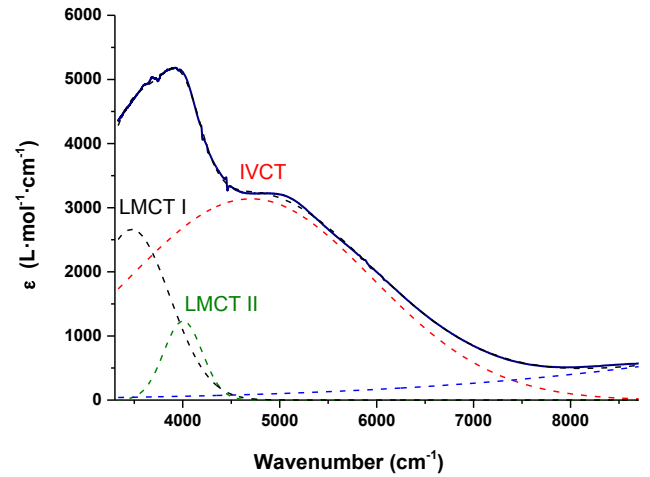

Figure 6. Four band Gaussian deconvolution of the NIR absorption envelope of [3a $]^{+}$obtained by spectroelectrochemistry in an OTTLE cell.

Further oxidation of $[3 \mathbf{a}]^{+}$and $[3 \mathbf{b}]^{+}$to the dications $[3 \mathbf{a}]^{2+}$ and $[3 \mathrm{~b}]^{2+}$ leads to a disappearance of the IVCT bands as homo-valent Fe(III/III) species are formed. In association with this, two MLCT transitions are emerged at ca. $1000 \mathrm{~nm}\left(10000 \mathrm{~cm}^{-1}\right)$. The LMCT bands that are determined for $[3 a]^{+}$and $[3 b]^{+}$can also be found in dications $[3 \mathbf{a}]^{2+}$ and $[3 \mathbf{b}]^{2+}$ exhibiting a decreased intensity (ca. 200 $\mathrm{L} \mathrm{mol}^{-1} \mathrm{~cm}^{-1}$ ) (Supporting Information).

Computational Studies. To explore the electronic structures of $[3 \mathrm{a}, \mathrm{b}]^{\mathrm{n}+}(\mathrm{n}=0,1,2)$ in more detail, the computational model

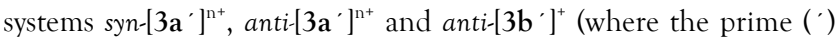
nomenclature is introduced to distinguish the computational from real system) were analyzed (B3LYP using Dunning's all-electron valence double zeta (D95V) for $\mathrm{C}$ and $\mathrm{H}$ atoms, and the Los Alamos ECP/double zeta valence basis set on $\mathrm{Fe}$ and $\mathrm{Si}$ (LANL2DZ) and a CPCM-dichloromethane solvent model). Tables of orbital energy and composition are given in the supporting information, together with the results from benchmarking studies carried out on $3 \mathrm{a}^{\prime}$ using $3-21 \mathrm{G}^{*}$ (all atoms), and $6-31 \mathrm{G}^{* *}(\mathrm{H}, \mathrm{C}, \mathrm{Si})$ / LANL2DZ (Fe) basis sets which reveal no structural or electronic differences of any significance to the results reported in the main body of the paper.

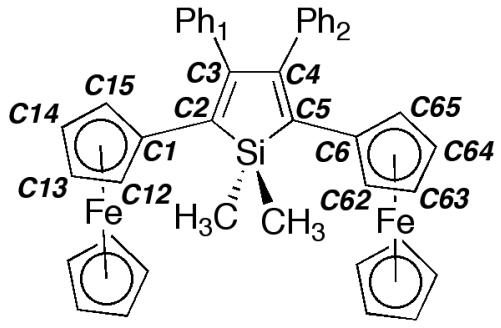

Figure 7. The atom labelling scheme of $3 a$.

The optimized geometry of syn-3a' compares very well with that determined crystallographically for $3 \mathbf{a}$ (Figure 7, Table 3), and differs little from that of anti-3a', which lies only $+0.37 \mathrm{~kJ} / \mathrm{mol}$ lower in energy. The optimized geometries of the syn- and anticonformer of $3 \mathrm{a}^{\prime}$ both exhibit pronounced bond-length alternation in the silacyclopentadiene ring, and significant cis-diene-like character in the bridging moiety linking the two ferrocenyl fragments, in a manner entirely analogous to the crystallographically determined stuctures of $3 \mathrm{a}, \mathrm{b}$ and other heterocyclic bridged bis(ferrocenyl) complexes. In both 
computational models as well as the crystallographically determined structures, the C1-C15, silacyclopentadiene and C6C65 rings are essentially co-planar, whilst the geometry at $\mathrm{Si}$ is distorted from idealized tetrahedral by the inclusion within the $\mathrm{C}_{4} \mathrm{Si}$ ring. The HOMO of syn-3a' features a substantial (ca. $42 \%$ ) character from the cis-butadiene-like portion of the silacycle, admixed with contributions from the ferrocenyl substituents (ca. $28 \%$ each) (Figure 8). There is negligible contribution from both the $\mathrm{SiMe}_{2}$ fragment and the phenyl groups, the latter being oriented approximately perpendicularly to the plane of the silacycle. The electronic structure varies little as a function of the relative disposition of the ferrocenyl moieties across the silacyclic ring, and the composition and energy of the frontier orbitals of the anti-conformer anti-3a are essentially the same as those described for the syn-form (Supporting Information).

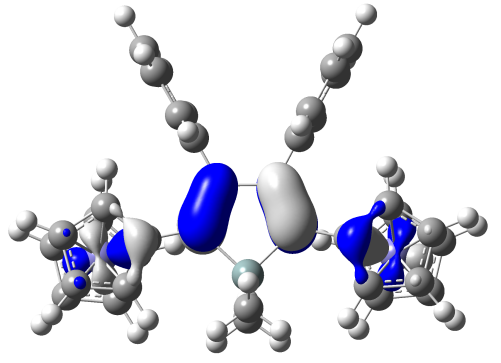

Figure 8. Plot of the $\mathrm{HOMO}$ of $3 \mathrm{a}^{\prime}$ (isocontour value \pm 0.04 $\left.\left(\mathrm{e} / \mathrm{bohr}^{3}\right)^{1 / 2}\right)$

Table 3. Selected Bond Lengths $(\AA \AA)$, Bond and Torsion Angles $\left(^{\circ}\right)$ from the Crystallographically Determined Structure of $3 a$ and the Optimized Geometry of Models $\left[3 \mathrm{a}^{\prime}\right]^{\mathrm{n}+}(\mathrm{n}=0,1,2)$.

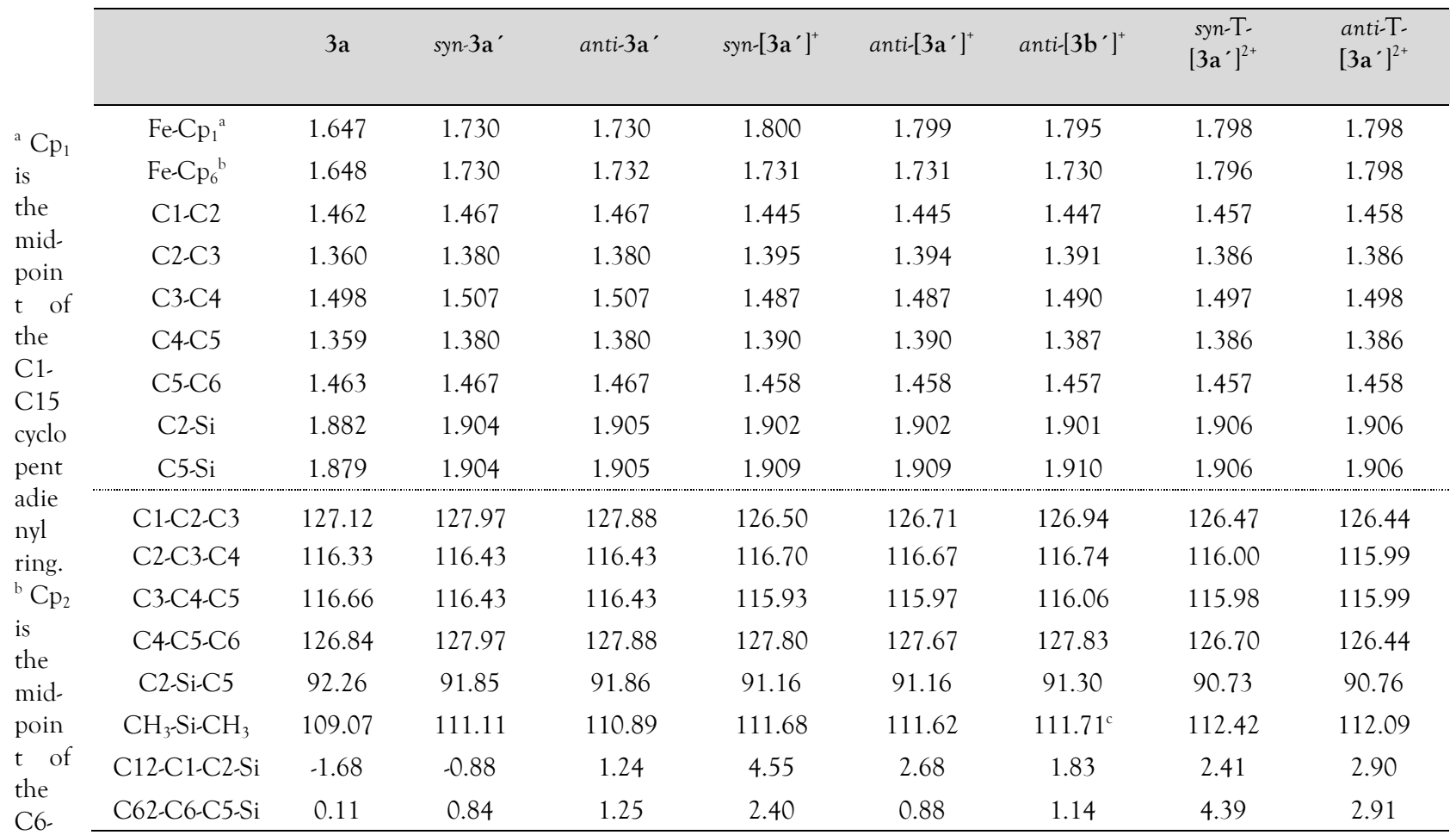

C65 cyclopentadienyl ring. ${ }^{\mathrm{c}}$ Read (ipso-C)-Si-(ipso-C)

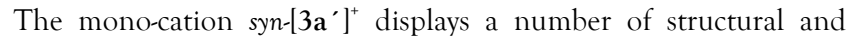
orbital features that are entirely consistent with the description of this species as an Fe(II/III) mixed-valence (MV) complex. The C1$\mathrm{C} 2$ bond is rather shorter in the monocation $(1.445 \AA)$ than in the neutral $(1.467 \AA)$, although the C5-C6 bond lengths are more consistent between the two oxidation states $\left(3 \mathrm{a}^{\prime} 1.467\right.$; $\left[3 \mathrm{a}^{\prime}\right]^{+}$ $1.458 \AA$ ), whilst within the silacyclopentadiene ring, the bond length alternation is modestly less pronounced (Table 3), giving rise to a valence bond description with more cumulenic character in the diene-like backbone. There is also a substantial elongation of the $\mathrm{Fe}-\mathrm{Cp}^{\mathrm{a}}$ distance in $\left[3 \mathrm{a}^{\prime}\right]^{+}$compared with $3 \mathrm{a}^{\prime}$, consistent with the oxidation of this site. However, there is little variation in the local geometry at the silicon center. The composition of the molecular orbitals also supports the MV description of $[3 \mathbf{a}]^{+}$, with the $\beta$-LUSO in $\left[3 \mathbf{a}^{\prime}\right]^{+}$essentially localized ( $80 \%$ ) on one ferrocenyl center and a small contribution (14\%) from the diene-like backbone (Figure 9), whilst the $\beta$-HOSO has more character derived from the other ferrocenyl moiety ( $58 \%$ ) and the diene (30 $\%$ with $10 \%$ arising from the formally oxidized ferrocenyl center (Figure 10). 


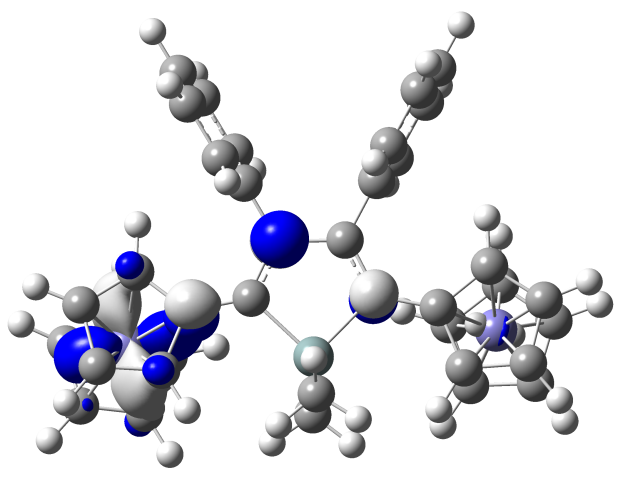

Figure 9. Plot of the -LUSO of $\left[3 \mathrm{a}^{\prime}\right]^{+}$(isocontour value \pm 0.04 $\left.\left(\mathrm{e} / \mathrm{bohr}^{3}\right)^{1 / 2}\right)$

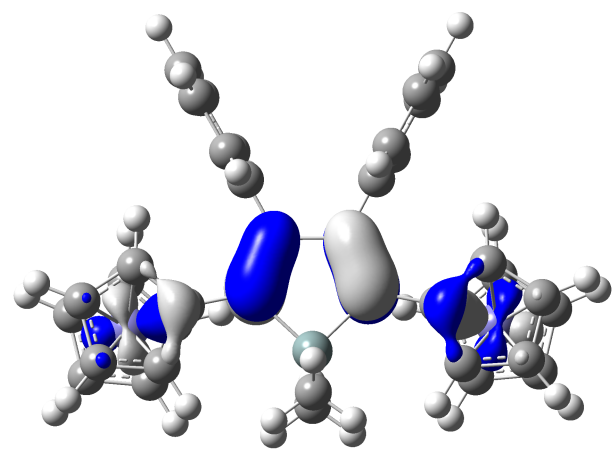

Figure 10. Plot of the $-\mathrm{HOSO}$ of $\left[3 \mathrm{a}^{\prime}\right]^{+}$(isocontour value \pm 0.04 $\left.\left(\mathrm{e} / \mathrm{bohr}^{3}\right)^{1 / 2}\right)$.

Interestingly, anti-[3 $\left.\mathbf{a}^{\prime}\right]^{+}$is essentially isoenergetic with the synisomer, lying barely $0.65 \mathrm{~kJ} / \mathrm{mol}$ lower in energy. This together with the virtually barrierless rotation determined from the dynamic NMR studies, indicates that solutions of [3a]+ contain more than

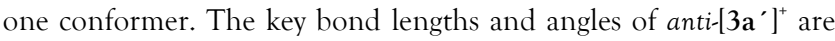
to all intents identical to those of the syn isomer, and there would also therefore appear to be little by way of net reorganization energy in the interconversion of the two conformers. The composition of

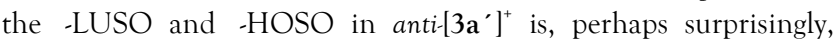
almost indistinguishable from that of the syn-conformer, with the LUSO being largely localized on one ferrocenyl moiety (81\%) and the diene $(14 \%)$ with the $-\mathrm{HOSO}$ again exhibiting more diene-like character ( $\mathrm{Fc} 59 \%$, diene $30 \%, \mathrm{Fc}^{+} 10 \%$ ) and being somewhat more delocalized.

In order to probe the possible conformational and chemical differences of the mixed-valence complexes $\left[2,5-\mathrm{Fc}_{2}-3,4-\mathrm{Ph}_{2}\right.$

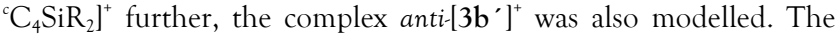
presence of the phenyl substituents made essentially no change to the core geometry of the cis-diene-like $\mathrm{Fc}^{+}-\mathrm{C}=\mathrm{CPh}-\mathrm{CPh}=\mathrm{C}-\mathrm{Fc}$

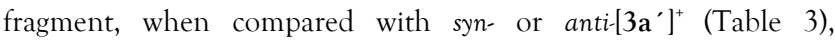
although the ferrocenyls are slightly distorted from co-planarity ( $\mathrm{Fe}$ -

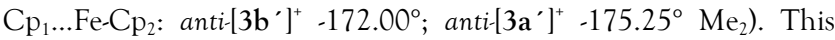
minor geometric variation, and the impact on the electronic structure, is potentially interesting with regards the suggestions of a degree of attenuation of the coupling between the ferrocenyl moieties through the 1,1,3,4-tetraphenylsilacyclopentadiene scaffold of $[3 b]^{+}$vs $[3 a]^{+}$made on the basis of the electrochemical and NIR data. Whilst the -LUSO of this lowest energy geometry of anti-[3$\left.b^{\prime}\right]^{+}$exhibits the same composition as in syn- and anti $-\left[3 a^{\prime}\right]^{+}$
$\left(\mathrm{Fc}^{+} 80 \%\right.$, diene $15 \%$, Fc $4 \%$ ), the diene contribution to the -

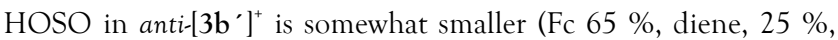
$\mathrm{Fc}^{+} 8 \%$ ). Given that the IVCT transition is approximated in terms of the $-\mathrm{HOSO} \rightarrow$-LUSO transition, the lower overlap between these orbitals may be responsible for the modestly weaker coupling. Such suggestions must be tempered against the relatively high barriers to rotation about the C1-C2 and C5-C6 bonds determined by dynamic NMR arising from the T-shaped $\pi-\pi$ interactions, and taken in light of the likely conformational distribution in solution. The notion that the $\mathrm{SiPh}_{2}$ moiety presents a steric barrier to the optimal co-planar arrangement of the ferrocenyl and silacyclic moieties, would be consistent with the modestly weaker coupling observed in $[3 \mathrm{~b}]^{+}$than in $[3 \mathrm{a}]^{+}$.

As an aside, we note that at the level of theory employed, a local minimum with a symmetric (i.e. delocalized or class III) electronic

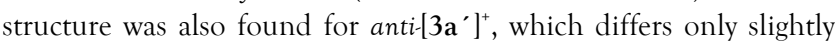
in individual bond lengths and is only $14 \mathrm{~kJ} / \mathrm{mol}$ higher in energy that the class II form described above (Supporting Information). Given the well-known over-estimation of delocalized electronic structures from the B3LYP functional, it is not appropriate to base any substantive comment on the apparently low energy difference

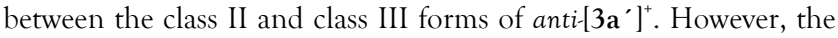
point to note is not that the B3LYP hybrid functional identifies a structure with a delocalized electronic structure, but rather that there are only very subtle changes in bond length required to pass between class II and class III in these complexes (a point that is implicit in the thermal barrier to electron transfer associated with class II complexes).

The dication syn- $\left[3 \mathrm{a}^{\prime}\right]^{2+}$ proved to be substantially more stable in the triplet (or high-spin, HS) ground state $\left(\mathrm{E}_{\mathrm{T} . \mathrm{s}}:-118.6 \mathrm{~kJ} / \mathrm{mol}\right.$ $\left.\left[3^{\prime}\right]^{2+}\right)$, and consequently the discussions here are restricted to this state. The molecular geometry of HS- $\left[3 \mathbf{a}^{\prime}\right]^{2+}$ reflects the homovalent nature of the two iron centers, with essentially identical geometric parameters observed in each half of the dication, and a restoration of the more pronounced bond-length alternation in the cis-diene backbone (Table 3). The dication is therefore well described as two ferrocenium moieties pendant to the silacycle.

\section{CONCLUSION}

The synthesis of 2,5-diferrocenyl-3,4-diphenyl siloles bearing methyl (3a) or phenyl (3b) groups at the silicon atom are realized by a reductive cyclization reaction of dimethyl- or diphenylbis(phenylethynyl)silane with lithium naphthalenide. The ferrocenyl substituents are introduced to the silole ring by Negishi $\mathrm{C}, \mathrm{C}$ cross-coupling reactions, whereas the siloles ring either was applied as vinyl halogenide or as zinc organic component. Electrochemical investigations showed that the ferrocenyl units of both synthesized siloles can be oxidized separately. In contrast to findings among the series of aromatic diferrocenyl five-membered heterocycles, ${ }^{15,18,19,44,45}$ the more electron-rich siloles showed a lower redox separation between the individual ferrocenyl oxidation processes. Spectroelectrochemical investigations confirmed electron charge transfer interactions between the individual ferrocenyl termini across the silole linking unit, which are comparable to those found in diferrocenyl phosphole ${ }^{15}$ or diferrocenyl cisbutadiene systems ${ }^{43}$, arguing that the $\mathrm{C}_{4}$ chain at the molecule's backbone mediates the electronic coupling. Molecules $[3 \mathrm{a}, \mathrm{b}]^{+}$can be characterized as moderate or moderate to weakly coupled class II species according to Robin and Day. Despite being more electronrich, $3 \mathrm{~b}^{+}$showed less intense IVCT absorptions than dimethylsilole $\left[3 \mathbf{a}^{+}\right.$, which may be due to steric interactions. DFT calculations are consistent with the class II mixed valence 
description of $[3 \mathbf{a}, \mathbf{b}]^{+}$, with the apparent low differences in energy between syn and anti conformations suggesting a distribution of molecular geometries, and hence variation in electronic coupling, in solution.

\section{EXPERIMENTAL SECTION}

General conditions. All reactions were carried out under an atmosphere of argon using standard Schlenk techniques. Tetrahydrofuran were purified by distillation from sodium/benzophenone ketyl. For column chromatography alumina with a particle size of $90 \mathrm{~m}$ (standard, Merck KGaA) was used.

Reagents. 2,5-Dibromo-1,1-dimethyl-3,4-diphenyl-1H-silole ${ }^{59}$ and diphenylbis(phenylethnyl)-silane ${ }^{60}$ were prepared in analogy to published procedures. $\left[\mathrm{N}\left({ }^{n} \mathrm{Bu}\right)_{4}\right]\left[\mathrm{B}\left(\mathrm{C}_{6} \mathrm{~F}_{5}\right)_{4}\right]$ was prepared by methathesis of lithium tetrakis-(pentafluorophenyl)borate etherate (Boulder Scientific) with tetra-n-butylammonium bromide according to reference, $\left.{ }^{35}\left[\mathrm{P}^{\mathrm{t}} \mathrm{C}_{4} \mathrm{H}_{9}\right)_{2} \mathrm{C}\left(\mathrm{CH}_{3}\right)_{2} \mathrm{CH}_{2} \mathrm{Pd}(-\mathrm{Cl})\right]_{2}{ }^{61,62}$ and iodoferrocene $\mathrm{e}^{63,64}$ were prepared according to published procedures. All other chemicals were purchased from commercial suppliers and were used as received.

Instrumentation. Infrared spectra were recorded using a FTNicolet IR 200 equipment. The ${ }^{1} \mathrm{H}$ NMR spectra were recorded with a Bruker Avance III 500 spectrometer operating at 500.303 $\mathrm{MHz}$ in the Fourier transform mode; the ${ }^{13} \mathrm{C}\left\{{ }^{1} \mathrm{H}\right\}$ NMR spectra were recorded at $125.800 \mathrm{MHz}$. Chemical shifts are reported in ppm downfield from tetramethylsilane with the solvent as reference signal $\left({ }^{1} \mathrm{H}\right.$ NMR: $\left(\mathrm{CHCl}_{3}\right)=7.26 \mathrm{ppm} ;{ }^{13} \mathrm{C}\left\{{ }^{1} \mathrm{H}\right\} \mathrm{NMR}:\left(\mathrm{CHCl}_{3}\right)=$ $\mathrm{CDCl}_{3}$, d $\left.77.16 \mathrm{ppm},{ }^{29} \mathrm{Si}\left\{{ }^{1} \mathrm{H}\right\} \mathrm{NMR}: \quad(\mathrm{TMS})=0.00 \mathrm{ppm}\right)$. The melting points were determined using a Gallenkamp MFB 595010 $\mathrm{M}$ melting point apparatus. Elemental analyses were performed with a Thermo FlashEA 1112 Series instrument. High resolution mass spectra were recorded using a micrOTOF QII Bruker Daltonite workstation. UV-vis spectra were recorded with a THERMO Genesys 6 spectrometer.

X-ray Diffraction: Data were collected with an Oxford Gemini S diffractometer at $110 \mathrm{~K}$ using Mo-K ( = $0.71073 \AA$ ) radiation. The structures were solved by direct methods and refined by full-matrix least square procedures on $\mathrm{F}^{2}{ }^{25,66}$ All non-hydrogen atoms were refined anisotropically, and a riding model was employed in the treatment of the hydrogen atom positions.

Electrochemistry. Electrochemical measurements on $1.0 \mathrm{mmol} \mathrm{L}$ 1 solutions of the analytes in dry air free dichloromethane containing $0.1 \mathrm{~mol} \mathrm{~L}^{-1}$ of $\left[\mathrm{N}^{n} \mathrm{Bu}_{4}\right]\left[\mathrm{B}\left(\mathrm{C}_{6} \mathrm{~F}_{5}\right)_{4}\right]$ as supporting electrolyte were conducted under a blanket of purified argon at $25^{\circ} \mathrm{C}$ utilizing a Radiometer Voltalab PGZ 100 electrochemical workstation interfaced with a personal computer. A three electrode cell, which utilized a Pt auxiliary electrode, a glassy carbon working electrode (surface area $0.031 \mathrm{~cm}^{2}$ ), and an $\mathrm{Ag} / \mathrm{Ag}^{+}\left(0.01 \mathrm{~mol} \mathrm{~L}^{-1} \mathrm{AgNO}_{3}\right)$ reference electrode mounted on a Luggin capillary was used. The working electrode was pretreated by polishing on a Buehler microcloth first with a $1 \mathrm{~m}$ and then a $1 / 4 \mathrm{~m}$ diamond paste. The reference electrode was constructed from a silver wire inserted into a solution of $0.01 \quad \mathrm{~mol} \mathrm{~L}^{-1} \quad\left[\mathrm{AgNO}_{3}\right]$ and $0.1 \quad \mathrm{~mol} \quad \mathrm{~L}^{-1}$ $\left[\mathrm{N}^{n} \mathrm{Bu}_{4}\right]\left[\mathrm{B}\left(\mathrm{C}_{6} \mathrm{~F}_{5}\right)_{4}\right]$ in acetonitrile, in a Luggin capillary with a vycor tip. This Luggin capillary was inserted into a second Luggin capillary with a vycor tip filled with a $0.1 \mathrm{~mol} \mathrm{~L}^{-1}\left[\mathrm{~N}^{n} \mathrm{Bu}_{4}\right]\left[\mathrm{B}\left(\mathrm{C}_{6} \mathrm{~F}_{5}\right)_{4}\right]$ solution in dichloromethane. ${ }^{36}$ Successive experiments under the same experimental conditions showed that all formal reduction and oxidation potentials were reproducible within $5 \mathrm{mV}$. Experimentally potentials were referenced against an $\mathrm{Ag} / \mathrm{Ag}^{+}$ reference electrode but results are presented referenced against ferrocene as an internal standard as required by IUPAC. ${ }^{42}$ When decamethylferrocene was used as an internal standard, the experimentally measured potential was converted into $E$ vs $\mathrm{FcH} / \mathrm{FcH}^{+}$by addition of $619 \mathrm{mV} .{ }^{67}$ Data were then manipulated on a Microsoft Excel worksheet to set the formal reduction potentials of the $\mathrm{FcH} / \mathrm{FcH}^{+}$couple to $E^{\circ}=0.0 \mathrm{~V}$. Ferrocene itself showed a redox potential of $220 \mathrm{mV}$ vs. $\mathrm{Ag} / \mathrm{Ag}^{+}\left(E_{\mathrm{p}}=61 \mathrm{mV}\right)$ within our measurements. ${ }^{68,69}$ The cyclic voltammograms, which are depicted (Figure 4), were taken after typical two scans and are considered to be steady state cyclic voltammograms in which the signal pattern differs not from the initial sweep.

Spectroelectrochemistry. UV-vis/NIR measurements were carried out in an OTTLE (optically thin layer electrochemistry) cell with quartz windows similar to that described previously ${ }^{70}$ in dry dichloromethane solutions containing $2.0 \mathrm{mmol} \mathrm{L}^{-1}$ analyte and 0.1 mol L $\mathrm{L}^{-1}$ of $\left[\mathrm{N}^{n} \mathrm{Bu}_{4}\right]\left[\mathrm{B}\left(\mathrm{C}_{6} \mathrm{~F}_{5}\right)_{4}\right]$ as supporting electrolyte using a Varian Cary 5000 spectrophotometer at $25^{\circ} \mathrm{C}$. The working electrode Ptmesh, the $\mathrm{AgCl}$ coated $\mathrm{Ag}$ wire for reference and the Pt-mesh auxiliary electrode are melt-sealed into a polyethylene spacer. The values obtained by deconvolution could be reproduced within $\max$ $=100 \mathrm{~L} \mathrm{~mol}^{-1} \mathrm{~cm}^{-1},{ }_{\max }=50 \mathrm{~cm}^{-1}$ and ${ }_{1 / 2}=50 \mathrm{~cm}^{-1}$. Between the spectroscopic measurements the applied potentials have been increased step-wisely using step heights of 25,50 or $100 \mathrm{mV}$. At the end of the measurements the analyte was reduced at $-400 \mathrm{mV}$ for $30 \mathrm{~min}$ and an additional spectrum was recorded to prove the reversibility of the oxidations.

Computational chemistry. Calculations were carried out with the Gaussian $09^{71}$ package , with GaussView 5.0.8 ${ }^{72}$ and GaussSum $3.0^{73}$ used to further analyse the results. All geometries were optimized with the B3LYP functional, using the LAN2DZ basis set on $\mathrm{Fe}$, and $6-31 \mathrm{G}^{* *}$ on all other atoms, with a CPCM (dichloromethane) solvent model. All optimized geometries were confirmed as true minima by absence of imaginary frequencies.

Synthesis of 2,5-diferrocenyl-1,1-dimethyl-3,4-diphenyl-1H-silole (3a). To a solution of $9.52 \mathrm{mmol}$ ferrocenyl zinc chloride in $40 \mathrm{~mL}$ of tetrahydrofuran, prepared by monolithiation of ferrocene $(1.95$ g, $10.47 \mathrm{mmol})^{74}$ followed by addition of $\left[\mathrm{ZnCl}_{2} \cdot 2 \mathrm{thf}\right](4.23 \mathrm{~g}$, $15.08 \mathrm{mmol})$ at $-80{ }^{\circ} \mathrm{C}$, was added 2,5-dibromo-1,1-dimethyl-3,4diphenylsilole $(2.0 \mathrm{~g}, 10.47 \mathrm{mmol})$ in a single portion at $25^{\circ} \mathrm{C}$. To the solution was added $16.3 \mathrm{mg}$ of $(24 \mathrm{~mol})$ $\left[\mathrm{P}\left({ }^{\mathrm{t}} \mathrm{C}_{4} \mathrm{H}_{9}\right)_{2} \mathrm{C}\left(\mathrm{CH}_{3}\right)_{2} \mathrm{CH}_{2} \mathrm{Pd}(-\mathrm{Cl})\right]_{2}$ and the mixture was stirred for $2 \mathrm{~d}$ at $80{ }^{\circ} \mathrm{C}$. After evaporation of all volatiles, the precipitate was dissolved in $70 \mathrm{~mL}$ of diethyl ether and washed three times with 60 $\mathrm{mL}$ portions of water. The organic phase was dried over $\mathrm{MgSO}_{4}$ and all volatiles were removed. The remaining crude solid was purified by column chromatography (column size $20 \times 4 \mathrm{~cm}$, on alumina) using a $n$-hexane-dichloromethane mixture of ratio 2:1 $(v / v)$ as eluent. All volatiles were removed under reduced pressure and the wine-red solid was crystallized from $n$-hexane at $68^{\circ} \mathrm{C}$. Yield: $35 \%$ (based on 2,5-dibromo-1,1-dimethyl-3,4-diphenylsilole). Anal. Calcd for $\mathrm{C}_{38} \mathrm{H}_{34} \mathrm{Fe}_{2} \mathrm{Si}\left(\mathrm{M}=630.45 \mathrm{~g} \mathrm{~mol}^{-1}\right)$ : $\mathrm{C} 72.39$, H 5.44; found: C 71.89, H 5.38. Mp: $275^{\circ} \mathrm{C}$ decomp.. IR ( $\mathrm{KBr}$, in $\left.\mathrm{cm}^{-1}\right)$ : $3087(\mathrm{w}), 3076(\mathrm{~m}), 3056(\mathrm{~m}), 3022(\mathrm{~m}), 2947(\mathrm{w}), 2923(\mathrm{w})$, 1682 (w), 1442 (m), 1241 (s), 1106 (s) 1000 (s), 793 (s), 745 (s), 702 (s), 506 (s). ${ }^{1} \mathrm{H} \mathrm{NMR}\left(\mathrm{CDCl}_{3}\right.$, in ppm): $0.73\left(\mathrm{~s}, 6 \mathrm{H}, \mathrm{CH}_{3}\right), 3.71$ $\left(\mathrm{pt}, J_{\mathrm{HH}}=1.89 \mathrm{~Hz}, 4 \mathrm{H}, \mathrm{C}_{5} \mathrm{H}_{4}\right), 4.06\left(\mathrm{~s}, 10 \mathrm{H}, \mathrm{C}_{5} \mathrm{H}_{5}\right), 4.10\left(\mathrm{pt}, J_{\mathrm{HH}}=\right.$ $\left.1.89 \mathrm{~Hz}, 4 \mathrm{H}, \mathrm{C}_{5} \mathrm{H}_{4}\right), 6.96-7.00\left(\mathrm{~m}, 4 \mathrm{H}, o-\mathrm{C}_{6} \mathrm{H}_{5}\right), 7.09-7.14(\mathrm{~m}, 2 \mathrm{H}$, p- $\left.\mathrm{C}_{6} \mathrm{H}_{5}\right)$ 7.18-7.22 (m, 4H, m- $\left.\mathrm{C}_{6} \mathrm{H}_{5}\right) .{ }^{13} \mathrm{C}\left\{{ }^{1} \mathrm{H}\right\}$ NMR $\left(\mathrm{CDCl}_{3}\right.$, in ppm): - $1.0\left(\mathrm{CH}_{3}\right), 68.6\left(\mathrm{C}_{5} \mathrm{H}_{4}\right), 68.7\left(\mathrm{C}_{5} \mathrm{H}_{4}\right), 69.5\left(\mathrm{C}_{5} \mathrm{H}_{5}\right), 83.3(i \mathrm{C}-$ $\left.\mathrm{C}_{5} \mathrm{H}_{4}\right), 126.4\left({ }_{0}-\mathrm{C}_{6} \mathrm{H}_{5}\right), 128.0\left(m-\mathrm{C}_{6} \mathrm{H}_{5}\right), 129.3\left(p-\mathrm{C}_{6} \mathrm{H}_{5}\right), 134.8(2,5-$ $\left.\mathrm{C}_{4} \mathrm{Si}\right), 141.6\left({ }^{i}-\mathrm{C}_{6} \mathrm{H}_{5}\right), 152.6\left(3,4-\mathrm{C}_{4} \mathrm{Si}\right) .{ }^{29} \mathrm{Si}\left\{{ }^{1} \mathrm{H}\right\} \mathrm{NMR}\left(\mathrm{CDCl}_{3}\right.$, in ppm): 5.70 (s, Si). UV-vis: $391 \mathrm{~nm}\left(12057 \mathrm{~L} \mathrm{~mol}^{-1} \mathrm{~cm}^{-1}\right), 507 \mathrm{~nm}$ (5073 $\left.\mathrm{L} \mathrm{mol}^{-1} \mathrm{~cm}^{-1}\right)$. HRMS (ESI-TOF, $\mathrm{m} / z$ ): calcd. for $\mathrm{C}_{38} \mathrm{H}_{34} \mathrm{Fe}_{2} \mathrm{Si}$ : 630.1129; found 630.1198 [M] $]^{+}$Crystal Data for $3 b: \mathrm{C}_{38} \mathrm{H}_{34} \mathrm{Fe}_{2} \mathrm{Si}$, 
$\mathrm{M}_{\mathrm{r}}=630.44 \mathrm{~g} \mathrm{~mol}^{-1}$, orthorhombic, $P$ b c $a,=0.71073 \AA, a=$ 13.036(5) $\AA, b=19.934(5) \AA, c=22.598(5) \AA, V=5872(3) \AA^{3}, Z=$ 8, calcd $=1.426 \mathrm{~g} \mathrm{~m}^{3},=1.023 \mathrm{~mm}^{1}, \mathrm{~T}=110 \mathrm{~K}$, range 3.1326 .00 $\circ, 56340$ reflections collected, 5734 independent reflections $\left(\mathrm{R}_{\text {int }}=\right.$ 0.0338), $\mathrm{R} 1=0.0258, \quad \mathrm{wR}_{2}=0.0635(\mathrm{I}>2(\mathrm{I})$ ).

Synthesis of 2,5-diferrocenyl-1,1,3,4-tetraphenyl-1H-silole (3b). Lithium naphthalenide was prepared by stirring $84.5 \mathrm{mg}(12.18$ mmol) of lithium with $1.56 \mathrm{~g}(12.18 \mathrm{mmol})$ of naphthalene in 10 $\mathrm{mL}$ of dry tetrahydrofuran at room temperature for $18 \mathrm{~h}$. To this solution were added $1.17 \mathrm{~g}(3.04 \mathrm{mmol})$ of (diphenylbis(phenylethynyl)silane in a single portion and the mixture was stirred for $1 \mathrm{~h}$. Afterward, $3.41 \mathrm{~g}(12.18 \mathrm{mmol})$ of $\left[\mathrm{ZnCl}_{2} \cdot 2\right.$ thf $]$ was added in a single portion at $0{ }^{\circ} \mathrm{C}, 10 \mathrm{~mL}$ of dry tetrahydrofuran were added and the mixture was stirred again for $1 \mathrm{~h}$. Iodoferrocene $(1.97 \mathrm{~g}(6.33 \mathrm{mmol}))$ and $12 \mathrm{mg}(17.5 \mathrm{~mol})$ of $\left[\mathrm{P}\left({ }^{t} \mathrm{C}_{4} \mathrm{H}_{9}\right)_{2} \mathrm{C}\left(\mathrm{CH}_{3}\right)_{2} \mathrm{CH}_{2} \mathrm{Pd}(-\mathrm{Cl})\right]_{2}$ were added and the reaction mixture was stirred for $2 \mathrm{~d}$ at $80{ }^{\circ} \mathrm{C}$. After evaporation of all volatiles, the solid material was dissolved in $40 \mathrm{~mL}$ of diethyl ether and washed three times with $30 \mathrm{~mL}$ portions of water. The organic phase was dried over $\mathrm{MgSO}_{4}$ and all volatiles were removed. The remaining crude solid was purified by column chromatography (column size $20 \times 2 \mathrm{~cm}$, on alumina) using a $n$-hexanedichloromethane mixture of ratio $4: 1(v / v)$ as eluent. All volatiles were removed under reduced pressure and the wine-red solid was crystallized from $n$-hexane at $68{ }^{\circ} \mathrm{C}$. Yield: $12 \%$ (based on diphenyl-bis(phenylethynyl)silane. $\mathrm{C}_{48} \mathrm{H}_{38} \mathrm{Fe}_{2} \mathrm{Si}\left(\mathrm{M}=754.59 \mathrm{~g} \mathrm{~mol}^{-}\right.$ $\left.{ }^{1}\right) . \mathrm{Mp}: 280{ }^{\circ} \mathrm{C}$ decomp.. IR ( $\mathrm{KBr}$, in $\left.\mathrm{cm}^{-1}\right)$ : 3089 (w), $3070(\mathrm{~m})$, 3048 (m), $3021(\mathrm{~m}), 1594(\mathrm{w}), 1557$ (m), $1483(\mathrm{~m}), 1429(\mathrm{~m}), 1267$ (s), 1112 (s), 1105 (s) 1000 (s), 819 (s), 770 (s) 735 (s), 706 (s), 504 (s). ${ }^{1} \mathrm{H} \mathrm{NMR}\left(\mathrm{CDCl}_{3}\right.$, in ppm): $3.52\left(\mathrm{~s}, 10 \mathrm{H}, \mathrm{C}_{5} \mathrm{H}_{5}\right), 3.57\left(\mathrm{pt}, J_{\mathrm{HH}}=\right.$ $\left.1.89 \mathrm{~Hz}, 4 \mathrm{H}, \mathrm{C}_{5} \mathrm{H}_{4}\right), 3.95\left(\mathrm{pt}, J_{\mathrm{HH}}=1.89 \mathrm{~Hz}, 4 \mathrm{H}, \mathrm{C}_{5} \mathrm{H}_{4}\right), 7.06-7.09$ $\left(\mathrm{m}, 4 \mathrm{H}, o_{-}-\mathrm{C}_{6} \mathrm{H}_{5}\right), 7.13-7.17\left(\mathrm{~m}, 2 \mathrm{H}, p-\mathrm{C}_{6} \mathrm{H}_{5}\right), 7.22-7.26(\mathrm{~m}, 4 \mathrm{H}, \mathrm{m}-$ $\left.\mathrm{C}_{6} \mathrm{H}_{5}\right), 7.52-7.55\left(\mathrm{~m}, 6 \mathrm{H}, \mathrm{Si}_{-} \mathrm{C}_{6} \mathrm{H}_{5}\right), 8.00-8.03\left(\mathrm{~m}, 4 \mathrm{H}, \mathrm{Si}_{-} \mathrm{C}_{6} \mathrm{H}_{5}\right)$. ${ }^{13} \mathrm{C}\left\{{ }^{1} \mathrm{H}\right\}$ NMR $\left(\mathrm{CDCl}_{3}\right.$, in ppm): $68.6\left(\mathrm{C}_{5} \mathrm{H}_{4}\right), 69.5\left(\mathrm{C}_{5} \mathrm{H}_{5}\right), 69.5$

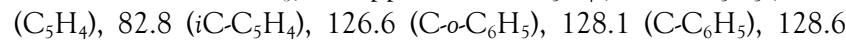
$\left(\mathrm{Si}-\mathrm{C}_{6} \mathrm{H}_{5}\right), 129.4\left(\mathrm{C}-\mathrm{C}_{6} \mathrm{H}_{5}\right), 130.5\left(\mathrm{Si}-\mathrm{C}_{6} \mathrm{H}_{5}\right), 133.5\left(\mathrm{C}_{6} \mathrm{H}_{5}\right), 133.8$ $\left(\mathrm{C}_{6} \mathrm{H}_{5}\right), 136.8\left(\mathrm{Si}_{-} \mathrm{C}_{6} \mathrm{H}_{5}\right), 141.6\left(i-\mathrm{C}_{6} \mathrm{H}_{5}\right), 154.8$ (3,4-C $\left.\mathrm{C}_{4} \mathrm{Si}\right)$. UV-vis: $398 \mathrm{~nm}\left(11846 \mathrm{~L} \mathrm{~mol}^{-1} \mathrm{~cm}^{-1}\right), 523 \mathrm{~nm}\left(5297 \mathrm{~L} \mathrm{~mol}^{-1} \mathrm{~cm}^{-1}\right)$. HRMS (ESI-TOF, $\mathrm{m} / \mathrm{z}$ ): calcd. for $\mathrm{C}_{48} \mathrm{H}_{38} \mathrm{Fe}_{2} \mathrm{Si}$ : 754.1442; found 754.1425 $[\mathrm{M}]^{+}$.

Crystal Data for 3b: $\mathrm{C}_{48} \mathrm{H}_{38} \mathrm{Fe}_{2} \mathrm{Si} \cdot 2 \mathrm{CH}_{2} \mathrm{Cl}_{2}, \mathrm{M}_{\mathrm{r}}=924.42 \mathrm{~g} \mathrm{~mol}^{-1}$, monoclinic, $P 2 / \mathrm{n}, a=13.1115(4) \AA, b=10.8183(4) \AA, c=$ 14.8040(4) $\AA, V=2073.56(12) \AA^{3}, Z=2$, calcd $=1.481 \mathrm{~g} \mathrm{~m}^{3}, \quad=$ $1.023 \mathrm{~mm}^{1}, \mathrm{~T}=110 \mathrm{~K}$, range $2.94224 .997^{\circ}$, 8460 reflections collected, 3644 independent reflections $\left(\mathrm{R}_{\mathrm{int}}=0.0205\right), \mathrm{R} 1=$ $0.0520, w_{R} 2=0.1284(\mathrm{I}>2(\mathrm{I}))$.

\section{ASSOCIATED CONTENT}

\section{Supporting Information}

Figures, Tables, and CIF files giving further (spectro)electrochemical spectra, computational data, and crystallographic data for $3 a$ and $3 b$. This material is available free of charge via the Internet at http://pubs.acs.org. Crystallographic data of $3 \mathbf{a}$ and $3 \mathbf{b}$ are also available from the Cambridge Crystallographic Database as file numbers CCDC 981390 (3a) and 981391 (3b).

\section{AUTHOR INFORMATION}

\section{Corresponding Author:}

*H.L.: e-mail, heinrich.lang@chemie.tu-chemnitz.de; tel, +49 (0)371-531-21210; fax, +49 (0)371-531-21219.

\section{Author Contributions}

\$Author to whom correspondence pertaining the calculations should be directed.

Notes

The authors declare no competing financial interest.

\section{ACKNOWLEDGEMENT}

We like to thank Dr. Holm Petzold for assistance with the dynamic NMR measurements. We are grateful to the Fonds der Chemischen Industrie for generous financial support. M.K. thanks the Fonds der Chemischen Industrie for a Chemiefonds fellowship. P.J.L. holds an Australian Research Council Future Fellowship (FT120100073) and gratefully acknowledges financial support for this work from the ARC (DP140100855).

\section{REFERENCES}

(1) Hongt, S. Y.; Marynick, D. S. Macromolecules 1995, 28, 49914995.

(2) Lu, G.; Usta, H.; Risko, C.; Wang, L.; Facchetti, A.; Ratner, M. A.; Marks, T. J. J. Am. Chem. Soc. 2008, 130, 7670-7685.

(3) Hong, Y.-R.; Wong, H.-K.; Moh, L. C. H.; Tan, H.-S.; Chen, Z.K. Chem. Commun. 2011, 47, 4920-4922.

(4) Wang, F.; Luo, J.; Yang, K.; Chen, J.; Huang, F.; Cao, Y. Macromolecules 2005, 38, 2253-2260.

(5) Tamao, K.; Yamaguchi, S.; Shiozaki, M.; Nakawaga, Y.; Ito, Y. J. Am. Chem. Soc. 1992, 114, 5867-5869.

(6) Ma, J.; Li, S.; Jiang, Y. Macromolecules 2002, 35, 1109-1115.

(7) Yamaguchi, Y.; Shioya, J. Mol. Eng. 1993, 339-347.

(8) Frapper, G.; Kertesz, M. Organometallics 1992, 11, 3178-3184.

(9) Zotti, G.; Martina, S.; Wegner, G.; Schlüter, A.-D. Adv. Mater. 1992, 798-801.

(10) Roncali, J. Chem. Rev. 1997, 97, 173-206.

(11) Zhao, Z.; Liu, D.; Mahtab, F.; Xin, L.; Shen, Z.; Yu, Y.; Chan, C. Y. K.; Lu, P.; Lam, J. W. Y.; Sung, H. H. Y.; Williams, I. D.; Yang, B.; Ma, Y.; Tang, B. Z. Chem. Eur. J. 2011, 17, 5998-6008.

(12) Li, C. B.; Yang, G. X.; Huang, Z. H.; Xin, Y.; Wang, C.; Yuan, J. H. Pigm. Resin Technol. 2009, 38, 387-391.

(13) Murata, H.; Kafafi, Z. H.; Uchida, M. Appl. Phys. Lett. 2002, $80,189$.

(14) Chen, H. Y.; Lam, W. Y.; Luo, J. D.; Ho, Y. L.; Tang, B. Z.; Zhu, D. B.; Wong, M.; Kwok, H. S. Appl. Phys. Lett. 2002, 81, 574.

(15) Miesel, D.; Hildebrandt, A.; Korb, M.; Low, P. J.; Lang, H. Organometallics 2013, 32, 2993-3002.

(16) Kaleta, K.; Strehler, F.; Hildebrandt, A.; Beweries, T.; Arndt, P.; Rüffer, T.; Spannenberg, A.; Lang, H.; Rosenthal, U. Chem. Eur. J. 2012, 18, 12672-12680.

(17) Kaleta, K.; Hildebrandt, A.; Strehler, F.; Arndt, P.; Jiao, H.; Spannenberg, A.; Lang, H.; Rosenthal, U. Angew. Chem. 2011, 123, 11444-11448.

(18) Hildebrandt, A.; Lehrich, S. W.; Schaarschmidt, D.; Jaeschke, R.; Schreiter, K.; Spange, S.; Lang, H. Eur. J. Inorg. Chem. 2012, 1114-1121.

(19) Hildebrandt, A.; Schaarschmidt, D.; Lang, H. Organometallics 2011, 30, 556-563.

(20) Speck, M.; Schaarschmidt, D.; Lang, H. Organometallics 2012, 1975-1982.

(21) Hildebrandt, A.; Pfaff, U.; Lang, H. Rev. Inorg. Chem. 2011, 31, $111-141$

(22) Hildebrandt, A.; Schaarschmidt, D.; van As, L.; Swarts, J. C.; Lang, H. Inorg. Chim. Acta 2011, 374, 112-118.

(23) Pfaff, U.; Hildebrandt, A.; Schaarschmidt, D.; Rüffer, T.; Low, P. J. Organometallics 2013, 32, 6106-6117. 
(24) Günther, H. Angew. Chem. Int. Ed. Engl. 1972, I, 861-874.

(25) Vignau, L.; Janot, J. New J. Chem. 2004, 1086-1090.

(26) Sinnokrot, M. O.; Valeev, E. F.; Sherrill, C. D. J. Am. Chem. Soc. 2002, 124, 10887-10893.

(27) Zhao, Y.; Truhlar, D. G. J. Phys. Chem. A 2005, 109, 42094212 .

(28) Chen, J.; Law, C. C. W.; Lam, J. W. Y.; Dong, Y.; Lo, S. M. F.; Williams, I. D.; Zhu, D.; Tang, B. Z. Chem. Mater. 2003, 15, 15351546.

(29) Tracy, H. J.; Mullin, J. L.; Klooster, W. T.; Martin, J. a; Haug, J.; Wallace, S.; Rudloe, I.; Watts, K. Inorg. Chem. 2005, 44, $2003-$ 2011.

(30) Yu, G.; Yin, S.; Liu, Y.; Chen, J.; Xu, X.; Sun, X.; Ma, D.; Zhan, X.; Peng, Q.; Shuai, Z.; Tang, B.; Zhu, D.; Fang, W.; Luo, Y. J. Am. Chem. Soc. 2005, 127, 6335-6346.

(31) Ferman, J.; Kakareka, J. P.; Klooster, W. T.; Mullin, J. L.; Quattrucci, J.; Ricci, J. S.; Tracy, H. J.; Vining, W. J.; Wallace, S. Inorg. Chem. 1999, 38, 2464-2472.

(32) Günther, H. NMR spectroscopy: basic principles, concepts, and applications in chemistry (2nd ed.) John Wiley \& Sons, New York, 1996.

(33) Neumann, R. C.; Jonas, V. J. Org. Chem. 1974, 39, 925-929.

(34) Barrière, F.; Geiger, W. E. J. Am. Chem. Soc. 2006, 128, 39803989.

(35) LeSuer, R. J.; Buttolph, C.; Geiger, W. E. Anal. Chem. 2004, 76, 6395-6401.

(36) Gericke, H. J.; Barnard, N. I.; Erasmus, E.; Swarts, J. C.; Cook, M. J.; Aquino, M. a. S. Inorg. Chim. Acta 2010, 363, 2222-2232.

(37) Hildebrandt, A.; Lehrich, S. W.; Schaarschmidt, D.; Jaeschke, R.; Schreiter, K.; Spange, S.; Lang, H. Eur. J. Inorg. Chem. 2012, 2012, 1114-1121.

(38) Pfaff, U.; Hildebrandt, A.; Schaarschmidt, D.; Hahn, T.; Liebing, S.; Kortus, J.; Lang, H. Organometallics 2012, 31, 67616771.

(39) Solntsev, P. V; Dudkin, S. V; Sabin, J. R.; Nemykin, V. N. Organometallics 2011, 30, 3037-3046.

(40) Goetsch, W. R.; Solntsev, P. V; Stappen, C. Van; Purchel, A. A.; Dudkin, S. V; Nemykin, V. N. Organometallics 2014, 33, 145157.

(41) Chong, D.; Slote, J.; Geiger, W. E. J. Electroanal. Chem. 2009, $630,28-34$.

(42) Gritzner, G.; Kuta, J. Pure Appl. Chem. 1984, 56, 461-466.

(43) Li, Y.; Josowicz, M.; Tolbert, L. M. J. Am. Chem. Soc. 2010, 132, 10374-10382.

(44) Hildebrandt, A.; Schaarschmidt, D.; Claus, R.; Lang, H. Inorg. Chem. 2011, 50, 10623-10632.

(45) Speck, M.; Claus, R.; Hildebrandt, A.; Ru, T.; Erasmus, E.; As, L. Van; Swarts, J. C.; Lang, H. Organometallics 2012, 6373-6380.

(46) Faustov, V. I.; Egorov, M. P.; Nefedov, M.; Molin, Y. N. Phys. Chem. Chem. Phys. 2000, 2, 4293-4297.

(47) Göransson, E.; Emanuelsson, R.; Jorner, K.; Markle, T. F.; Hammarström, L.; Ottosson, H. Chem. Sci. 2013, 4, 3522.

(48) Tibbelin, J.; Wallner, A.; Emanuelsson, R.; Heijkenskjöld, F.; Rosenberg, M.; Yamazaki, K.; Nauroozi, D.; Karlsson, L.; Feifel, R.; Pettersson, R.; Baumgartner, J.; Ott, S.; Ottosson, H. Chem. Sci. 2014, 5, 360.

(49) Emanuelsson, R.; Wallner, A.; Ng, E. a M.; Smith, J. R.; Nauroozi, D.; Ott, S.; Ottosson, H. Angew. Chem. Int. Ed. Engl. 2013, 52, 983-987.

(50) D’Alessandro, D. M.; Keene, F. R. Dalton Trans. 2004, 39503954.

(51) Low, P. J.; Brown, N. J. J. Clust. Sci. 2010, 21, 235-278.

(52) Hildebrandt, A.; Ruffer, T.; Erasmus, E.; Swarts, J. C.; Lang, H. Organometallics 2010, 29, 4900-4905.
(53) Hildebrandt, A.; Lang, H. Dalton Trans. 2011, 40, 1183111837.

(54) Hildebrandt, A.; Lang, H. Organometallics 2013, 32, 56405653.

(55) D’Alessandro, D. M.; Keene, F. R. Chem. Soc. Rev. 2006, 35, 424-440.

(56) Brunschwig, B. S.; Creutz, C.; Sutin, N. Chem. Soc. Rev. 2002, $31,168-184$.

(57) Lapinte, C. J. Organomet. Chem. 2008, 693, 793-801.

(58) Mücke, P.; Linseis, M.; Záliš, S.; Winter, R. F. Inorg. Chim. Acta 2011, 374, 36-50.

(59) Tamao, K.; Yamaguchi, S.; Shiro, M. J. Am. Chem. Soc. 1994, 11715-11722.

(60) Morra, N. A.; Pagenkopf, B. L. Org. Synth. 2008, 85, 53-63.

(61) Clark, H. C.; Goel, A. B.; Goel, R. G.; Goel, S.; Ogini, W. O. Inorg. Chim. Acta 1978, 31, L441-442.

(62) Goel, A. B.; Goel, S. Inorg. Chim. Acta 1985, 98, 67-70.

(63) Goeltz, J. C.; Kubiak, C. P. Organometallics 2011, 30, 39083910.

(64) Inkpen, M. S.; Du, S.; Driver, M.; Albrecht, T.; Long, N. J. Dalton Trans. 2013, 42, 2813-2816.

(65) Sheldrick, G. M. Acta Crystallogr. Sect. A Found. Crystallogr. 1990, 46, 467-473.

(66) Sheldrick, G. M. SHELXL-97, Progr. Crytsal Struct. Refinement 1997, University.

(67) Nafady, A.; Geiger, W. E. Organometallics 2008, 5624-5631.

(68) Ruiz, J. A.; Daniel, M.-C.; Astruc, D. Can. J. Chem 2006, 84, 288-299.

(69) Ruiz, J.; Astruc, D. Comptes Rendus l'Académie des Sci. - Ser. IIC Chem. 1998, 1, 21-27.

(70) Krejcik, M.; Danek, M.; Hartl, F. J. Electroanal. Chem. 1991, 317, 179-187.

(71) Frisch, M. J. . et al. Gaussian 09, Revis. D.01; Gaussian Inc. Wallingford CT J. 2009.

(72) Dennington, R.; Keith, T.; Millam, J. J. Semichem Inc., Shawnee Mission KS 2009.

(73) O’Boyle, N. M.; Tenderholt, A. L.; Langner, K. M. J. Comput. Chem. 2008, 29, 839-845.

(74) Sanders, R.; Mueller-Westerhoff, U. T. J. Organomet. Chem. 1996, 512, 219-224. 


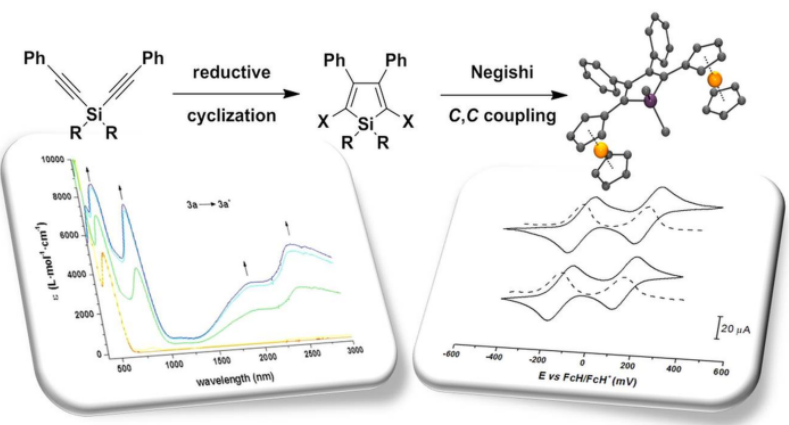

